$$
\begin{gathered}
\text { UNITED STATES } \\
\text { DEPARTMENT OF THE INTERIOR } \\
\text { GEOLOGICAL SURVEY } \\
\text { Water Resources Division }
\end{gathered}
$$

\title{
GEOLOGY, HYDROLOGY, AND QUALITY OF WATER IN THE HANFORD-VISALIA AREA \\ SAN JOAQUIN VALLEY, CALIFORNIA
}

\section{By}

M. G. Croft and G. V. Gordon

Prepared in cooperation with the California Department of Water Resources

\subsection{7 \\ OPEN-FILE REPORT}





\section{CONTENTS}

Abstract-1.

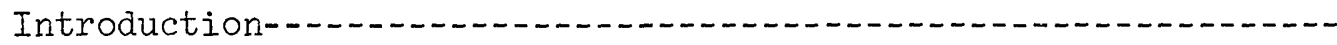

Purpose and scope of the investigation

Location and general description of the area-...........

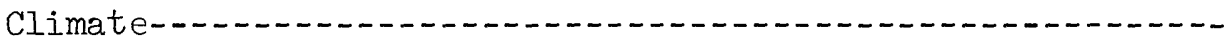

Previous investigations-....

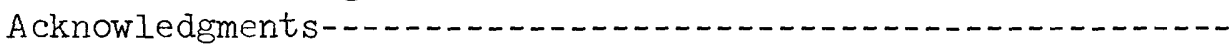

Well-numbering system-_...

Geomorphology-

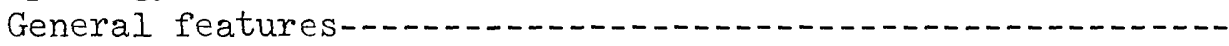

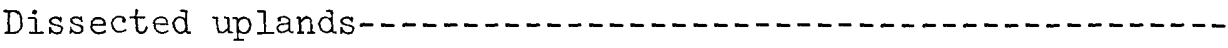

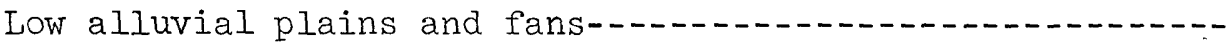

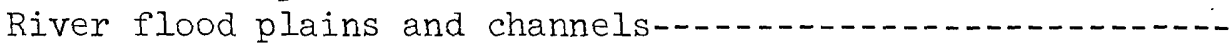

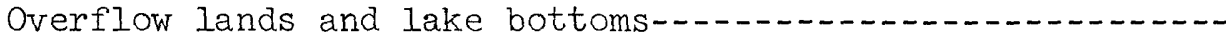

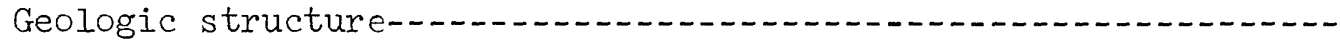

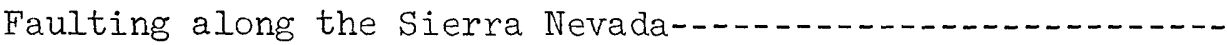

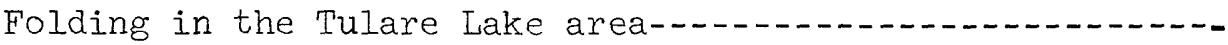

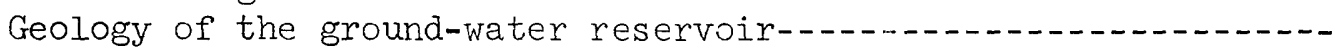

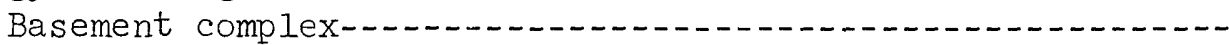

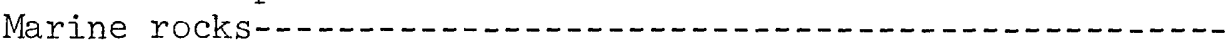

Unconsolidated deposits-1...

Continental deposits

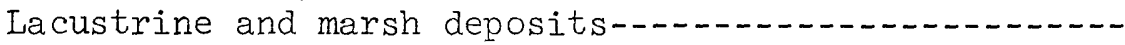

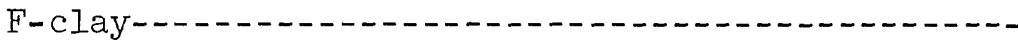

E-clay-.-.

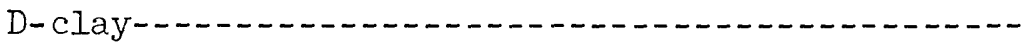

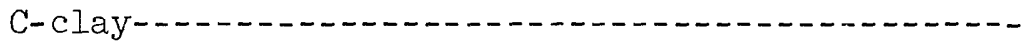

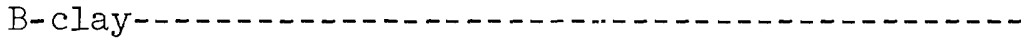

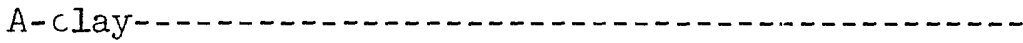

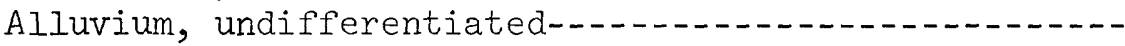

Older alluvium

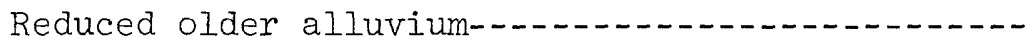

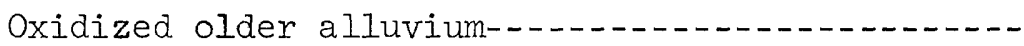

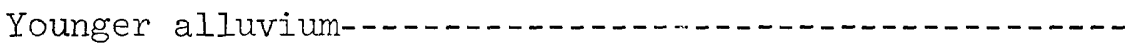

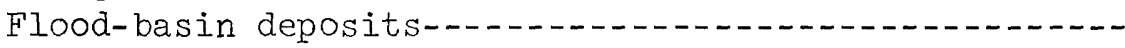

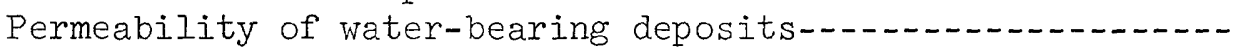

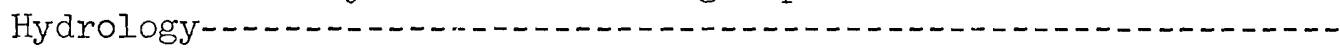

Water supply-

Ground-water conditions-...

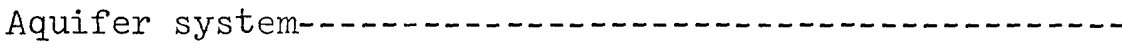

Unconfined and semiconfined

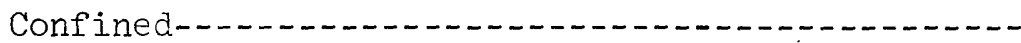

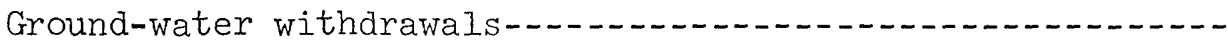

Page

1

3

3

5

5

8

9 
Hydrology--Continued

Hydrologic conditions by subareas-

Tule River subarea--

Lindsay subarea--

Kaweah River subarea-.

Ivanhoe subarea--

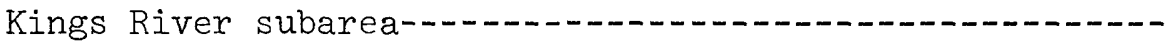

Tulare Lake subarea-...

Summary of water supply-...

Chemical quality of water-

Surface water

Perennial streams

Intermittent streams

Ground water.

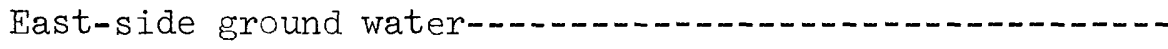

In the younger alluvium and oxidized older alluvium

In the continental deposits and reduced older

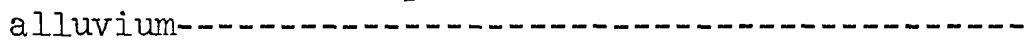

Axial-trough ground water-...

Above the A-clay-cond

Between the A- and E-clays-...

Below the E-clay-...

Chemical quality of ground water in relation to use-..-.--

Irrigation-....

Salinity- Sodiunt.

Sodium-1--

Domestic use

Artificial recharge-

Existing sites-_... 56

Recharge basins...... 56

River channels-_... 58

Potential sites-. 58

Selected references-1. 59

\section{ILLUSTRATIONS}

\section{[Plates are in pocket]}

Plate 1. Map showing geomorphic features of the Hanford-Visalia area, San Joaquin Valley, California.

2. Geologic map of the Hanford-Visalia area, San Joaquin Valley, California.

3. Map and sections showing structure and depth to basement complex, Hanford-Visalia area, San Joaquin Valley, California.

4. Geologic section $A-A^{\prime}$.

5. Geologic section $B-B^{\prime}$.

6. Geologic section $\mathrm{C}-\mathrm{C}^{\prime}$.

7. Geologic sections $D_{-} D^{\prime}$ and $E-E^{\prime}$. 
Plate 8. Maps showing structure and extent of lacustrine clays, Hanford-Visalia area, San Joaquin Valley, California.

9. Structure contours on the base of the oxidized older alluvium, Hanford-Visalia area, San Joaquin Valley, California.

10. Map and diagrammatic section showing relative permeability of geologic units as interpreted from yield factors, Hanford-Visalia area, San Joaquin Valley, California.

II. Water-level and piezometric-contour map, autumn 1961 and winter 1962, Hanford-Visalia area, San Joaquin Valley, California.

12. Graphs showing relation between water supply, evapotranspiration demand, and water-level fluctuations, Hanford-Visalia area, San Joaquin Valley, California.

13. Map showing chemical character of selected surface and ground water, Hanford-Visalia area, San Joaquin Valley, California.

14. Map showing areal distribution of ground-water types, Hanford-Visalia area, San Joaquin Valley, California.

15. Map showing chemical character of ground water below the E-clay, Hanford-Visalia area, San Joaquin Valley, California.

Page

Figure 1. Index map

2. Graphs showing climatic data-... 7

3. Log of core hole 20S/19E-3IP_........ 21

4. Log of core hole 2IS/26E-35J2_........ 26

5. Hydrographs of piezometer tubes $20 \mathrm{~S} / 26 \mathrm{E}-24 \mathrm{KI}$ and K2-..- 33

6. Hydrographs of piezometer tubes 2IS/24E-3IDI and D2--.- 35

7. Hydrograph of well 19S/21E-9FI_................... 37

8. Representative hydrographs of wells near Visalia and an accumulated departure curve of the Kaweah River.....- 42

9. Vertical bar graphs representing average chemical analyses of water from perennial Sierra Nevada and

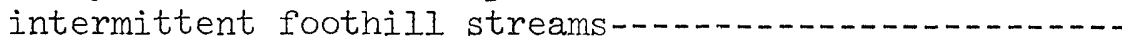

48

\section{TABLES}

Table 1. Generalized section of the geologic units of Sierra Nevada origin and their water-bearing

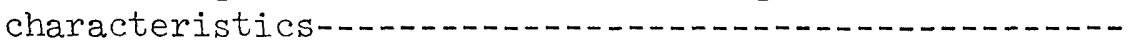

2. Ground-water pumpage in the Hanford-Visalia area-.......

3. Summary of surface supplies and demand for irrigation

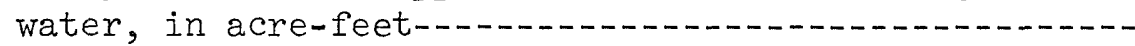

4. Water supply available for irrigated land in the

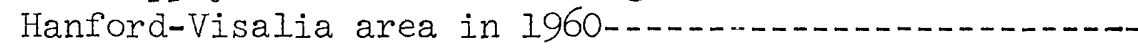

5. Recharge capacity and percolation rates in recharge basins and reservoirs-... 


\section{GEOLOGY, HYDROLOGY, AND QUALITY OF WATER IN THE HANFORD-VISALIA AREA SAN JOAQUIN VALLEY, CALIFORNIA}

By M. G. Croft and G. V. Gordon

\section{ABSTRACT}

The Hanford-Visalia area is in the southeastern part of the San Joaquin Valley, about 30 miles south of Fresno, Calif. Agriculture, the principal industry of the area, is dependent upon irrigation water from streams flowing from the high Sierra Nevada on the east and upon water pumped from the ground-water reservoir during the warm, dry summer.

The rocks that crop out in the Hanford-Visalia area are (1) a relatively impermeable basement complex of pre-Tertiary age, composed of consolidated metamorphic and igneous rocks, and (2) unconsolidated deposits of Pliocene, Pleistocene, and Recent age which contain fresh water. In addition to the exposed rocks, consolidated marine rocks generally containing brackish water occur in the subsurface. The unconsolidated deposits are the source of most of the ground water pumped in the area. On the east side of the valley, these deposits consist of arkosic material derived from the Sierra Nevada and are divided into three stratigraphic units--continental deposits, older alluvium, and younger alluvium. On the west side of the valley, the unconsolidated deposits consist of alluvium, undifferentiated, composed of material eroded from the coast Ranges. In the center of the valley, flood-basin, lacustrine, and marsh deposits interfinger with deposits from the east and west sides of the valley.

The continental deposits of Pliocene and Pleistocene(?) age are divided into oxidized and reduced deposits on the basis of depositional environment. The oxidized deposits, which crop out along the eastern margin of the valley, consist of a few feet to 500 feet of deeply weathered, poorly permeable, reddish-brown sandy silt and clay with well-developed soil profiles. The reduced deposits are moderately permeable and consist of micaceous sand, silt, and clay that extend across the trough in the subsurface to the west side of the valley. 
Lacustrine and marsh deposits, of Pliocene and Pleistocene age, consist of blue, green, or gray silty clay and fine sand and underlie the floodbasin deposits. They extend to about 3,000 feet in depth and crop out in the Kettleman Hills. In the subsurface, around the margins of Tulare lake Bed, the lacustrine and marsh deposits form six extensive tongues or zones that interfinger with more permeable beds of the continental deposits, alluvium, undifferentiated, and the older alluvium. The lacustrine and marsh deposits and the clay tongues are aquitards that control the vertical and lateral movement of ground water.

Older alluvium of Pleistocene and Recent(?) age unconformably overlies the continental deposits, is moderately to highly permeable, and is the major aquifer in the area. The older alluvium, like the continental deposits, is divided into oxidized and reduced deposits. The oxidized deposits consist of reddish-mottled, highly permeable, crossbedded, fluviatile arkosic sand with lenses of gravel and, rarely, thick beds of silt or clay. Soil profiles are well developed. The reduced deposits consist mainly of moderately permeable, unweathered, fine to medium sand, silty sand, and clay, sporadically cemented with calcium carbonate. Generally, gravel is absent.

Younger alluvium of Recent age consists of arkosic beds, moderately to highly permeable, fluviatile sand, and silty sand beneath broad, nearly featureless flood plains. Soil profiles are poorly developed or absent. The unit generally is less than 55 feet thick and is an aquifer only in the vicinity of Hanford and Lemoore.

The aquifer system contains ground water under unconfined, semiconfined, and confined conditions. In general, ground water is unconfined in the oxidized older alluvium, the younger alluvium, and in the flood-basin deposits. Ground water is semiconfined in the oxidized and reduced continental deposits and in the reduced and some of the oxidized older alluvium. Confined aquifers occur in the reduced continental deposits and reduced older alluvium below and between impermeable lacustrine clays in the vicinity of Tulare Lake Bed.

The area was divided into six subareas for determining the response of the aquifers to known quantities of inflow and outflow. The period studied (water years 1956 through 1960) included 2 wet years and 3 dry years. Water supply exceeded demand in the wet years and was deficient in dry years. Deficiencies were made good with water pumped from underground storage. Water levels in the Hanford-Visalia area generally declined during this period. Gross ground-water withdrawal is estimated to be $1,240,000$ acre-feet in the 1955-56 water year and 2,070,000 acre-feet in the 1959-60 water year. 
Ground water in the unconsolidated deposits beneath the alluvial fans, on the east side of the valley, is generally low in dissolved constituents. Sodium and bicarbonate are the principal ions in ground water in the continental deposits and in the reduced older alluvium. Sodium constitutes more than 70 percent of the cations in the water from these deposits. Total dissolved solids range from 100 to $500 \mathrm{mg} / \mathrm{l}$ (milligrams per liter). Magnesium and chloride are major constituents in the water in the interfan areas.

Ground water in the oxidized older alluvium and younger alluvium is generally of the calcium bicarbonate type. Where recharge is from the major streams, sodium constitutes less than 42 percent of the cations and total dissolved solids range from 100 to $270 \mathrm{mg} / 1$. In the interfan areas where recharge is from intermittent streams, dissolved constituents range from 270 to $650 \mathrm{mg} / \mathrm{I}$ and magnesium and chloride are major constituents.

In the axial trough, ground water is generally high in mineral constituents and the content is variable. Ground water between the A-clay and the E-clay varies from the sodium bicarbonate to sodium sulfate types. The dissolved-solids content ranges from 200 to $1,100 \mathrm{mg} / \mathrm{l}$. Below the E-clay, ground water varies from sodium bicarbonate to sodium chloride type. Dissolved-solids content ranges from 500 to more than $1,000 \mathrm{mg} / \mathrm{l}$.

\section{INTRODUCTION}

\section{Purpose and Scope of the Investigation}

The California Water Plan (California Department of Water Resources, 1957), provides for transfer of surplus water from the northern areas of California to areas of need in the southern part of the state. This plan includes cyclic artificial recharge and underground storage of large quantities of water transferred during periods of surplus and withdrawal of the stored water during periods of deficiency. A detailed knowledge of the geologic and hydrologic conditions of the ground-water reservoir is required in areas of water transfer such as the Hanford-Visalia area. Success of this plan will require efficient conjunctive use of both surfaceand subsurface-storage reservoirs.

The purpose of the investigation and report is to (1) supplement earlier general and specific problem studies by collecting, interpreting, and presenting data on the detailed geology and hydrology of the groundwater reservoir and its setting; (2) describe the geologic and hydrologic conditions as they relate to utilization of the area for ground-water storage; and (3) relate the study area to adjacent areas and to the valley as a whole. 
The scope of the investigation included (1) delineation of the surfaceand subsurface-geologic units and features in sufficient detail to define the ground-water reservoir and its subdivisions in terms of lithology, texture, thickness, areal extent, water-bearing characteristics, and relation to the valley area as a whole; (2) description of the hydrology of the area as it relates to the ground-water body or bodies within the reservoir, to the occurrence of the water bodies in relation to the geologic subdivisions of the reservoir, and to the movement of water within and between the water bodies in response to recharge and discharge;

(3) identification and description of the various water qualities in the area with special reference to distribution of zones of poor chemical quality of ground water which may affect recharge and withdrawal activities; and (4) specific appraisal of the geologic and hydrologic conditions as they relate to the possibilities for recharge of the ground-water reservoir and to the use of the reservoir for cyclic storage of transported water.

Fieldwork for this report was begun in October 1960 and completed in June 1962. Analysis of data and preparation of the report were started at the field headquarters in Visalia and were continued at the district office in Sacramento until 1963. Because other agencies had collected a vast amount of basic data, the Geological Survey utilized as much of their data as possible. Also, considerable data were available from previous reconnaissance surveys by Mendenhall and others (1916), and Davis and others (1959).

To supplement the available data, about 1,500 drillers' logs, 1,200 chemical analyses, and 500 electric logs were taken into the field, and the wells to which these data applied were field located. Information concerning depth of the well and perforated interval of its casing were obtained, where it was practicable to do so. The well information and selected chemical analyses of the water are available in the Sacramento office of the Water Resources Division, U.S. Geological Survey, as an open-file report (G. V. Gordon and M. G. Croft, 1964).

Areal geologic mapping consisted of tracing geologic contacts and inspecting the material exposed in road cuts and gravel pits. In some areas the surface geology is modified from soil maps. Fourteen test wells drilled by the U.S. Bureau of Reclamation provided valuable geologic, hydrologic, and quality-of-water data for the area. These are the only deep water wells for which detailed lithologic logs are available and the wells were completed for multiple-zone observation of water level and water quality at a single location. Geologic units mapped on the surface were correlated with deposits described in the logs of the core holes and - correlated with electric logs of adjacent wells. The structural contour maps and geologic sections in this report were constructed using the information obtained from these correlations. 
Location and General Description of the Area

The Hanford-Visalia area comprises about 2,000 square miles in the San Joaquin Valley (fig. l). This valley, a topographic and structural basin underlain by a thick accumulation of sediments, is bordered by the Sierra Nevada on the east, the Coast Ranges on the west, and the Tehachapi Mountains on the south. Southward from the Kings River, the San Joaquin Valley is, under present conditions, a basin of interior drainage tributary to several depressions in the valley trough. The largest of these depressions is Tulare Lake Bed in the southwest part of the Hanford-Visalia area which receives runoff from the Kaweah, Tule, and Kings Rivers.

About 1,700 square miles of the report area are within the valley, and about 300 square miles are in the foothills and lower slopes of the Sierra Nevada. The area is between long $118^{\circ} 45^{\prime} 00^{\prime \prime}$ and $120^{\circ} 00^{\prime} 00^{\prime \prime} \mathrm{W}$. and lat $36^{\circ} 00^{\prime} 00^{\prime \prime}$ and $36^{\circ} 30^{\prime} 00^{\prime \prime} \mathrm{N}$. The center of the area, about 30 miles south of Fresno, is midway between Sacramento and Los Angeles and is easily accessible via U.S. Highway 99. State Highways 41 and 198 connect the area with the coast. Highway 198 is also a gateway to Sequoia and Kings Canyon National Parks, 40 miles northeast of Visalia. The main rail line of the Southern Pacific Co. (pl. 2) parallels U.S. Highway 99 and together with branch lines serves the towns of Visalia, Hanford, Tulare, Exeter, Lindsay, and Porterville. The Atchinson, Topeka and Santa Fe Railway serves the towns of Hanford and Corcoran.

Farming and processing of agricultural products are the main industries of the area. A wide variety of crops includes oranges and lemons grown within a citrus belt about 10 miles wide adjacent to the foothills between Porterville and Ivanhoe. Grapes, nuts, peaches, and apricots are raised near Hanford, Visalia, Tulare, and Farmersville. Cotton, barley, and alfalfa are the main crops in the southern and western parts of the area. Raising of livestock is not as important as it was in the past. The three counties of the area--Fresno, Kings, and Tulare--are among the nation's leaders in total value of agricultural products harvested. Nonagricultural industry has been rare, but the processing of petroleum and the manufacture of rubber and electrical products are growing industries.

\section{Climate}

The climate in the southern part of the San Joaquin Valley is warm and dry, with long hot summers and short cool winters. Temperatures in midsummer are high, with daily maximums commonly exceeding $100^{\circ} \mathrm{F}$ but difference between day and night temperatures frequently is $40^{\circ} \mathrm{F}$ or more. The mean annual temperature, recorded at Visalia by the U.S. Weather Bureau, is $64^{\circ} \mathrm{F}$ (fig. 2). Lowest temperatures generally occur in December and January, and the highest temperatures occur in July. 


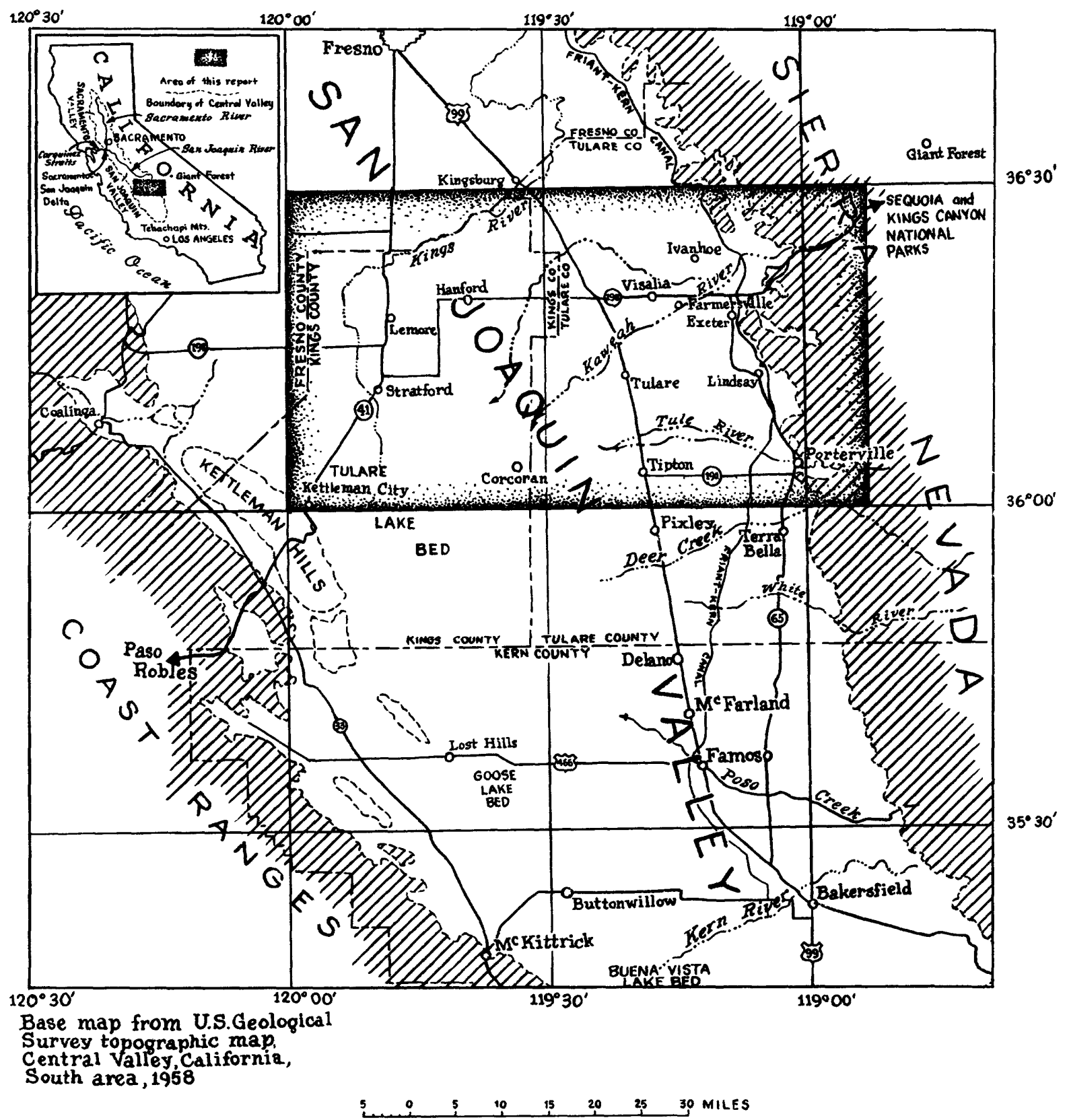

FIGURE 1.--Index map of the Hanford-Visalia area, San Joaquin Valley, California. 


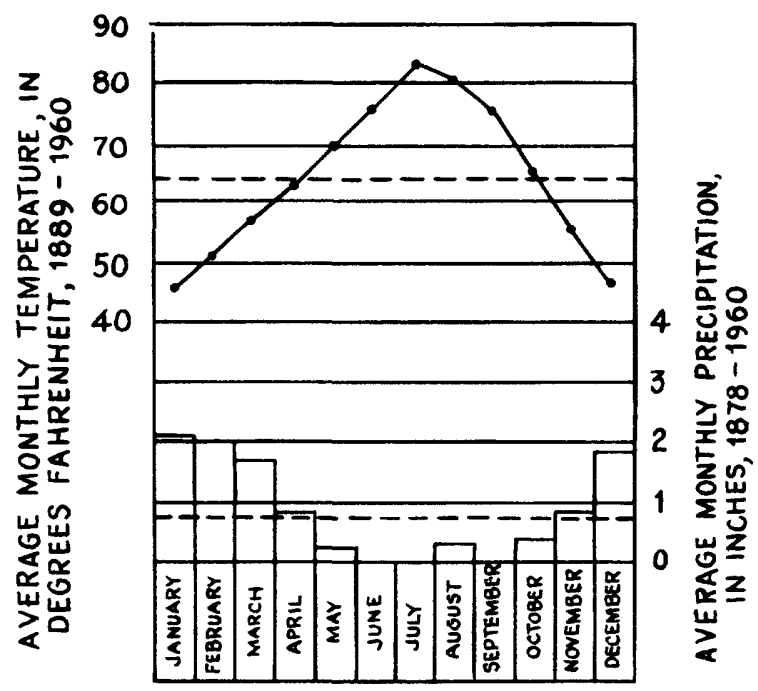

A.Precipitation and temperature at Visalia
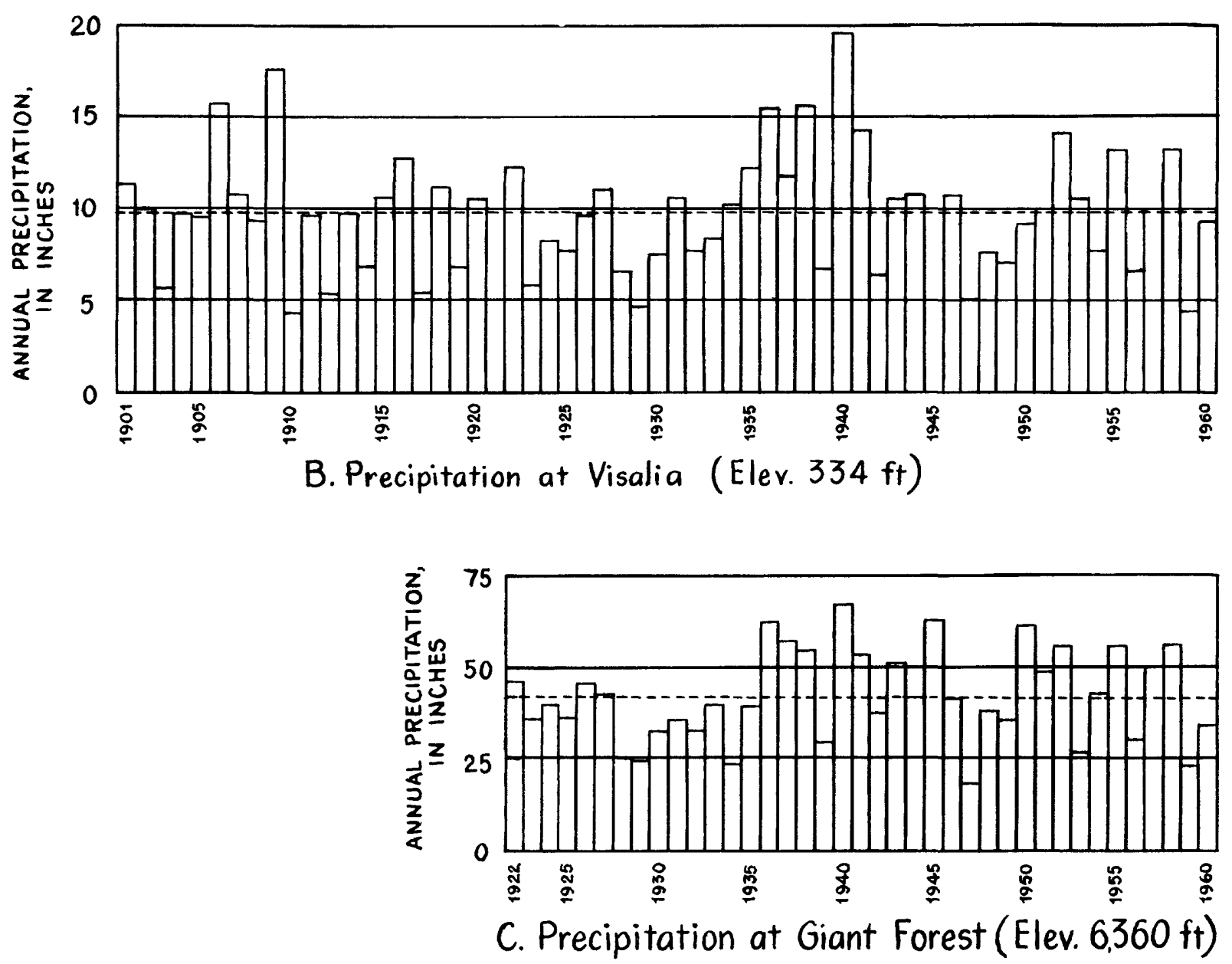
Precipitation in the San Joaquin Valley is scanty and decreases from north to south and from east to west across the valley as storms sweep in from the Pacific Ocean and ascend the Sierra Nevada. Annual precipitation at Visalia ranges from 4 to 19 inches and averages 9.4 inches. Precipitation is greater in the Sierra Nevada and averages 46.5 inches at Giant Forest (fig. I) in the upper part of the drainage basin of the Kaweah River. In the higher Sierra Nevada much of the precipitation occurs as snow, which melts during the spring and early summer.

\section{Previous Investigations}

Many reconnaissance reports of geologic and ground-water studies in the San Joaquin Valley have been prepared by federal and state agencies. A report on the early development of irrigation was prepared by Grunsky (1898). One of the earliest valleywide ground-water reconnaissance reports based on work done in 1905-07, when ground-water development was in its infancy, was by Mendenhall and others (1916) of the U.S. Geological Survey. The report outlined the status of ground-water development, and described the quality of the water. Harding (1927, p. 8) made a study of Kings, Tulare, and Kern Counties in the southern part of the valley to determine the relation of present use to the available supply. He pointed out that water levels were declining rapidly in areas of insufficient surface supplies. More recently Davis and others (1959) made a reconnaissance study of the San Joaquin Valley which outlined the principal geologic and hydrologic features that control the movement and determine the chemical character of ground water. In addition, the storage capacity was estimated for the upper 200 feet of valley fill. Davis and others (1964) made another study of the San Joaquin Valley that described the potential use of groundwater reservoirs for storage of surface water.

The U.S. Bureau of Reclamation has made geologic and ground-water investigations of the Exeter, Lower Tule River, Ivanhoe, and Porterville Irrigation Districts, but the results of their investigations are not in published form. Geologic studies were made in the adjoining Kettleman Hills by Woodring and others (1940) and in the foothills northeast of Visalia by Durrell (1940). Widespread correlation of lacustrine deposits in the San Joaquin Valley was made by Barbat and Galloway (1934), Frink and Kues (1954), and Davis and others (1959).

In addition to geologic and hydrologic studies, the Geological Survey has made studies of land subsidence in relation to geologic and hydrologic parameters in the Central Valley. One such study by Poland and Evenson (1966) describes the extent and magnitude of land subsidence caused chiefly by intensive pumping of ground water and the resulting decline of artesian head. Many other studies are listed in the selected references at the end of this report. 


\section{Acknowledgments}

The collection of data for this report and the successful completion of the investigation were made possible by the cooperation of public agencies, private companies, and individuals. Drillers' logs, soil logs and maps, and chemical analyses of water, were furniahed by the U.S. Bureau of Reclamation, the California Department of Water Resources, the California Water Service Co., the Agricultural Extension Service, and many private land companies. Copies of electric logs were obtained from commercial blueprint firms or were made available by Schlumberger Well Surveying Corp., Zublin Well Logging Corp., and the California Division of Oil and Gas, with the permission of well owners. Several hundred singlepoint electric logs were furnished by Geochemical Survey, Dallas, Tex. Results of pump-efficiency tests and electric-power figures were furnished by Pacific Gas and Electric Co. and Southern California Edison Co.

This report was prepared by the Geological Survey, Water Resources Division, in cooperation with the California Department of Water Resources as part of an investigation of the water resources of parts of Fresno, Kings, and Tulare Counties. The work was done under the general supervision of $R$. Stanley Lord, district chief in charge of water-resources investigations in California, and under the immediate supervision of W. W. Dean, chief of the Sacramento subdistrict office. R. W. Page, R. A. LeBlanc, Kenneth Muir, Kenneth Geringer, and F.W. Giessner assisted in the collection and preliminary analysis of data, the geologic mapping, and the preparation of the illustrations.

\section{We11-Numbering System}

Wells are assigned numbers according to their location in the rectangular system for the subdivision of public land. For example, in the number 19S/2IE-1BI, for a well near Hanford, the number and letter before the slash indicate the township (T. $19 \mathrm{S.}$ ) and those after the slash indicate the range ( $R_{.} 21 \mathrm{E}$ ), Mount Diablo base and meridian; the digit between the hyphen and the letter indicates the section (sec. I); and the letter after the section number indicates the 40-acre subdivision of the section as shown in the diagram below. A $Z$ after the section number indicates that the location of a well within a section has not been verified in the field, but the information supplied with the log indicates the location probably is accurate. Within each 40-acre tract, the wells are numbered serially as indicated by the final digit of the well number.

\begin{tabular}{|c|c|c|c|}
\hline D & C & B & A \\
\hline E & F & G & H \\
\hline M & L & K & J \\
\hline N & P & Q & R \\
\hline
\end{tabular}




\section{GEOMORPHOLOGY}

\section{General Features}

The San Joaquin Valley is in the southern and larger part of the Central Valley of California. It is about 250 miles long and extends from the Sacramento-San Joaquin delta area on the north to the Tehachapi Mountains on the south; it is about 40 miles wide between Kettleman City and Porterville. The principal geomorphic features in the Hanford-Visalia area are shown on plate 1 . The valley is bordered on the east by the westward-tilted Sierra Nevada whose altitude ranges from less than 1,000 feet in the foothills to more than 14,000 feet above sea level near the crest of the range. The Coast Ranges, bordering the valley on the west, consist of a series of folded and faulted marine and volcanic rocks which rise to about 6,000 feet above sea level. Alluvium derived from the adjacent mountains on the east and west forms the gently sloping valley floor.

The southern end of the San Joaquin Valley, also known as Tulare basin, has no present external drainage although through flow occurred under natural conditions. Under present conditions the streams drain to closed depressions; the largest of these is Tulare Lake Bed, the northern part of which is in the southwest corner of the report area (pl. 1). Davis and Green (1962, p. D90) suggested that Tulare Lake Bed is the surface expression of a structural depression flanking the Kettleman Hills anticlinal structure. The other two depressions--Buena Vista Lake Bed and Goose Lake Bed--are farther south, near Bakersfield (fig. 1). Three Rivers--Kings, Kaweah, and Tule--discharged into Tulare Lake before their flow was largely diverted for irrigation.

The geomorphic features as described by Davis and others (1959, p. 19-36) include dissected uplands, low alluvial plains and fans, river flood plains and channels, overflow land and lake bottoms, and the hills of the Coast Ranges on the west and the linear ridges and resistant inliers of the Sierra Nevada on the east.

\section{Dissected Uplands}

The dissected uplands include deeply weathered, eroded, and uplifted alluvial deposits east of Porterville, west of Lindsay Peak, and north of Cottonwood Creek (pl. 1). Scattered remnants of the uplands also occur as terraces in Yokohl Valley. Deep weathering and erosion have developed dark reddish-brown soils and gullies as much as 50 feet deep. The soils and the underlying deposits are fine grained and are poorly permeable. Because of their small areal extent, the dissected uplands are of little hydrologic significance. 
Low Alluvial Plains and Fans

The east side of the valley is a broad plain of low relief. The plain consists of three large, coalescing alluvial fans of streams draining the Sierra Nevada. A large coalescing alluvial fan of streams draining the Coast Ranges forms the valley floor northwest of Tulare Lake Bed. The Kings River alluvial fan is the largest fan on the east side of the area and is separated from the Kaweah River alluvial fan by Cross Creek (pl. 1). Elk Bayou separates the Kaweah River fan from the smaller Tule River fan to the south. The Kings River, which flows in the valley trough west of Lemoore, separates the Kings River fan from the fan of the west slope of the valley. Cottonwood and Lewis Creeks are intermittent streams that discharge into the interfan areas between the major rivers.

The low alluvial plains and fans are characterized by surfaces of low topographic relief, rarely exceeding 10 feet except near major streams. Near Tulare Lake Bed, where the altitude of the fans is about 200 feet, the surface is flat and nearly featureless. Near the mountains, at Porterville, Lindsay, and Exeter, where the altitude is nearly 500 feet, their surface becomes broadly rolling and is characterized by a microrelief of small mounds and closed depressions. The soils are generally sandy, permeable, and fertile, although hardpan is present in some areas. In the interfan areas and adjacent to Elk Bayou and Cross Creek the soils are alkaline and less fertile. The plains and fans form the largest part of the valley floor and constitute a highly developed agricultural area.

\section{River Flood Plains and Channels}

The river flood plains flank the channels of the Kaweah, Tule, and Kings Rivers. The Kings River is entrenched below the valley floor in much of the eastern part of the area, but the Kaweah and Tule Rivers are entrenched only on the upper parts of their alluvial fans.

The Kings River is the largest river discharging onto Tulare Lake Bed. It has the deepest trench and the largest alluvial fan. On the lower part of the river, where it forks near Laton (pl. l), the trenching becomes less distinct, and, in the past, the flood plain flared outward to include broad areas on both sides of the river. Artificial levees now confine the river and the flood plain to the channel. At high stage, a substantial part of the flow of the Kings River is toward Murphy Slough, which discharges into the San Joaquin River. The main southern distributary divides north of Lemoore, and both branches flow southward toward Tulare Lake Bed. 
The Kaweah River has an indistinct channel that generally is less than 5 feet deep, and its flood plain emerges from the Sierra Nevada directly onto the alluvial fan. Southwest of Woodlake the river divides into two branches which are largely confined by artificial levees. The northern branch is called the st. Johns River and it flows northward to become Cross Creek. The southern branch retains the name Kaweah River and, except in floods, all of its water is diverted for irrigation.

The Tule River flows westward from the Sierra Nevada in a shallow channel formed by artificial levees toward Tulare Lake Bed. The river channel is about 5 feet deep near Porterville and decreases in depth westward. Most of the flow of the river is diverted for irrigation in the upper part of the fan.

\section{Overflow Lands and Lake Bottoms}

Overflow lands and lake bottoms are flat nearly featureless areas in the valley trough that formerly were inundated during flood stages of Tulare Lake. The swampy area along the lower part of the Kings River also is included in this unit. The soils generally are poorly permeable, but they generally are fertile and mostly free from alkali. Mendenhall and others (1916, p. 281) indicated that the size of the area inundated by Tulare Lake ranged from dry in 1905 to about 800 square miles during 1861-63. Grunsky (1898, p. 16-17) reported that Tulare Lake may have been dry at intervals in the prehistoric past.

Overflow from Tulare Lake, through Murphy Slough into the San Joaquin River, is reported to have occurred when the lake surface reached an altitude of about 210 feet above sea level. Overflow has not occurred since 1878 (Davis and others, 1959, p. 29). Since 1919, the lakebed has been dry, except for several brief periods of flooding. At present the lakebed is intensively farmed, and levees control most of the floodwater entering the area. Under extreme flood conditions, the water from Buena Vista Lake, near Bakersfield, overflowed into Tulare Lake, and throughflow occurred throughout the length of the San Joaquin Valley, thus preventing the development of extensive salt flats. 
GEOLOGIC STRUCTURE

\section{Faulting Along the Sierra Nevada}

A series of en echelon faults are inferred to parallel the Sierra Nevada from Porterville to Monson. Lineations in the continental deposits are traceable on aerial photographs south of Porterville and terminate at the contact between the continental deposits and the older and younger alluvium. These features are inferred to represent fault traces (p1. 2). Between Porterville and Exeter the extension of the inferred fault trace is buried beneath the older and younger alluvium. The ridges that face the valley are here interpreted as faultline scarps, and the hills to the east are interpreted as having been carved from the upfaulted block (p1. 3). Inliers of basement complex do not occur west of the inferred fault zone. Near Ivanhoe and strathmore, steep crystalline-rock contacts buried beneath the valley fill are interpreted as having been formed by faulting.

Based on water-level data, there is no evidence of faulting in the older and younger alluvium. South of Porterville, water levels in the continental deposits were erratic, but data were insufficient to construct water-level maps that might indicate if faulting was the cause. North and east of Lindsay, marine rocks are found within a few hundred feet of the surface, presumably due to upfaulting. A driller's log for well

19S/27E-30PI, for example, recorded granite at 406 feet below land surface.

\section{Folding in the Tulare Lake Area}

According to Woodring and others (1940, p. 152-155), a surface of low relief developed across folded beds of the Tulare Formation and older underlying rocks in the Kettleman Hills. The main part of the deformation is believed to have preceded the deposition of the deposits they mapped as older alluvium. This surface was subsequently arched and modified by erosion. Because the Tulare Formation lies conformably upon the San Joaquin Formation in the Kettleman Hills and lies unconformably on Pliocene and older formations in the bordering mountains, Woodring and others (1940, p. 14) are of the opinion that the trough of the basin in which sediments of the San Joaquin and Tulare Formations were deposited is near the Kettleman Hills. 


\section{GEOLOGY OF THE GROUND-WATER RESERVOIR}

The rocks that crop out in the Hanford-Visalia area (p1. 2) include (1) the basement complex of pre-Tertiary age consisting of consolidated metamorphic and igneous rocks, and (2) unconsolidated deposits of Pliocene, Pleistocene, and Recent age, all of which contain fresh water. Consolidated marine rocks of Pliocene age and older do not crop out in this area but are penetrated in the subsurface by wells. Because the water from those wells generally is brackish or salty, the marine rocks are not considered as part of the fresh-water reservoir. Most of the ground water pumped within the area is from the unconsolidated deposits; therefore, they were studied in greater detail, with special reference to their water-bearing character. Table I summarizes the geologic units of Sierra Nevada origin and their water-bearing characteristics. Alluvium, undifferentiated, derived from a Coast Range source, is not shown in table 1 .

\section{Basement Complex}

The basement complex, of pre-Tertiary age, consists of metamorphic and igneous rocks. They underlie the Sierra Nevada and occur as resistant inliers in the alluvium and as linear ridges in the foothills along the east margin of the area. In the subsurface they slope steeply westward from the Sierra Nevada beneath the deposits of Cretaceous age and younger rocks that compose the valley fill. Plate 3 shows the depth below land surface and the altitude above or below sea level at which bedrock (presumably basement complex) was reported by drillers, or interpreted from electric logs. Part of the data was from May and Hewitt (1948), and Smith (1964). Cross sections (pl. 3, secs. F-F' and $G-G^{\prime}$ ) indicate escarpments that are interpreted as buried fault scarps. West of the escarpments the slope of the basement complex steepens. In the Tulare Lake area an oil-test well failed to penetrate the basement complex at 14,642 feet below sea level (Smith, 1964).

The basement complex is at shallow depth in the Lindsay, Strathmore, and Ivanhoe areas and in the intermontane valleys where it is penetrated by many water wells. North of Ivanhoe the basement complex forms a broad, gently westward-sloping shelf overlain by 100 to 1,000 feet of unconsolidated deposits. In T. $17 \mathrm{~S} ., \mathrm{R} .24 \mathrm{E}$., the basement complex drops abruptly to about 2,100 feet below land surface, presumably due to faulting. Logs of water wells indicate that the basement complex at Strathmore and in Frazier Valley is at a fairly uniform depth of 300 to 400 feet below land surface. About a mile west of Strathmore the basement complex is interpreted as downfaulted on cross section $J-J^{\prime}$ (pI. 3). 
Table 1.--Generalized section of the geologic units of Sierra Nevada origin and their water-bearing characteristics

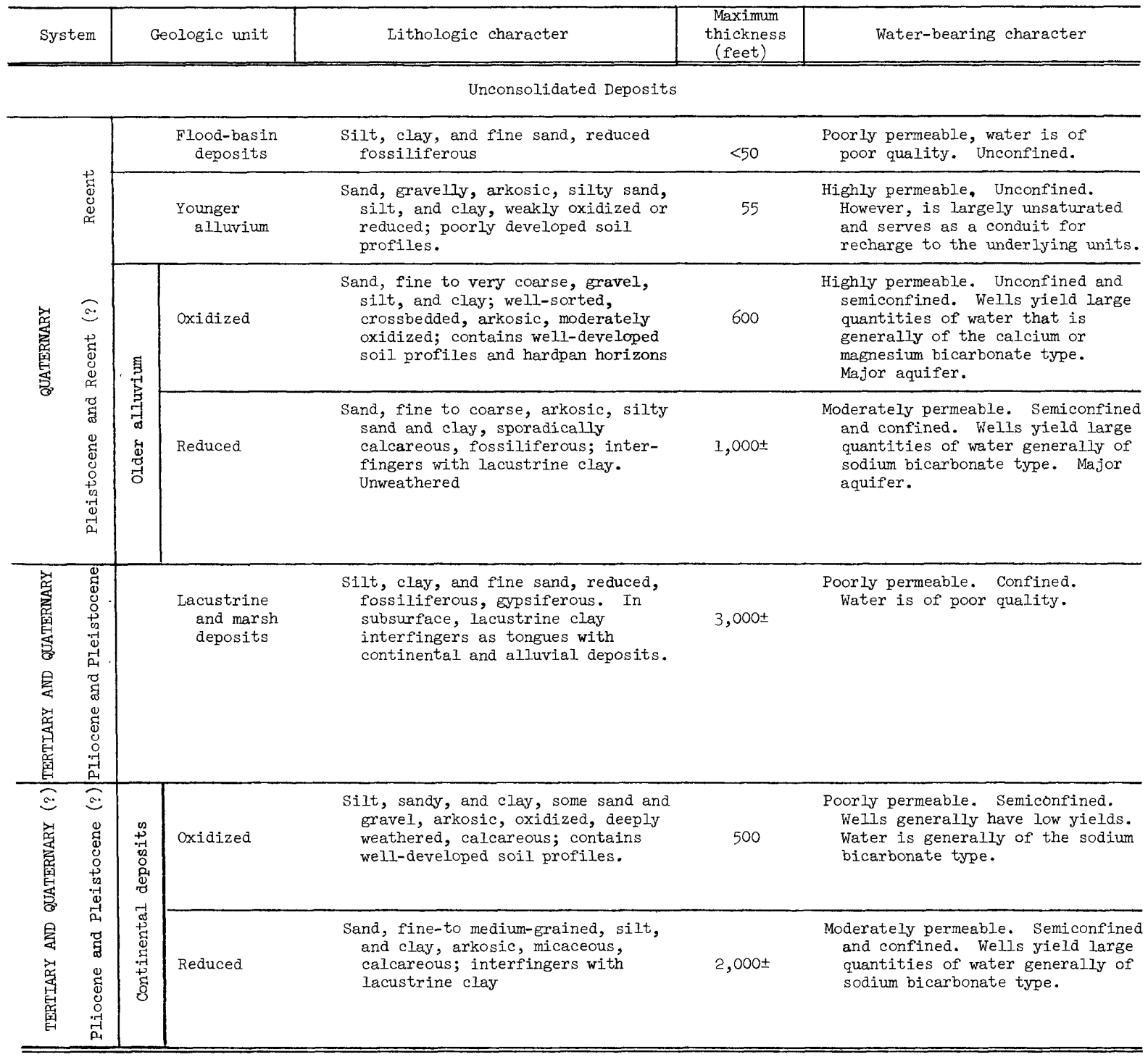

Consolidated Rocks

\begin{tabular}{|c|c|c|c|c|}
\hline 窟 & Marine rocks & Sandstone, siltstone, and shale & $12,000 \pm$ & $\begin{array}{l}\text { Generally do not yield fresh } \\
\text { water, contain mostly brackish } \\
\text { water. }\end{array}$ \\
\hline 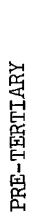 & $\begin{array}{l}\text { Basement } \\
\text { complex }\end{array}$ & Metamorphic and igneous rocks & & $\begin{array}{l}\text { Fractures, faults, and joints } \\
\text { locally yield small quantities } \\
\text { of water; otherwise virtually } \\
\text { impermeable. }\end{array}$ \\
\hline
\end{tabular}




\section{Marine Rocks}

Along the east border of the San Joaquin Valley, Tertiary rocks, mainly of marine origin, overlap the basement complex and underlie the unconsolidated deposits (pls. 4, 6, and 7). This unit may locally include beds of continental origin. In the area of this study the marine rocks do not crop out. In the northwestern part of the area near Riverdale, Cretaceous rocks overlie the basement complex and underlie the Tertiary section (Hunter, 1952). Eastward the Cretaceous rocks wedge out against the basement complex where they are overlapped by the Tertiary section. Cretaceous rocks were not identified in this investigation and are not shown in the geologic sections. The Tertiary marine rocks, penetrated by oil- and gas-test wells throughout the eastern part of the area, range in age from Eocene to late Pliocene and consist of consolidated to semiconsolidated sandstone, siltstone, and shale. They have been divided into several formations by oil geologists (Park and Weddle, 1959), but as they generally contain brackish and saline connate or dilute connate water unsuitable for most uses, they are treated here as one unit.

\section{Unconsolidated Deposits}

The unconsolidated deposits in this report are equivalent to strata which have in previous reports been divided into formal and informal geologic units. In the Kettleman Hills, in the southwest corner of the area of this investigation, Woodring and others (1940) divided the equivalent beds into the Tulare Formation and into older and younger alluvium. The Tulare Formation in the Kettleman Hills overlies the upper Mya zone (Woodring and others, 1940, p. 13), a fossil horizon at the top of the San Joaquin Formation. The Mya zone is reported in well logs beneath Tulare Lake Bed (p1. 4). The base of the unconsolidated deposits is projected, by electric log correlation, from the upper Mya zone beneath Tulare Lake Bed, eastward to the top of marine rocks reported in test well 20S/26E-24Kl (pI. 7). The unconsolidated deposits of this report, are equivalent to the continental deposits from the Sierra Nevada of Klausing and Lohman (1964) and to the unconsolidated deposits as used by Hilton and others (1963) in the Terra Bella-Lost Hills area to the south.

Within this study area, the unconsolidated deposits extend from the Sierra Nevada to the Coast Ranges. They overlie marine rocks beneath the valley, but along most of the Sierra Nevada front from Porterville to Yettem, and in the intermontane valleys, unconsolidated deposits unconformably overlie the basement complex. The unconsolidated deposits thicken from zero along the western front of the Sierra Nevada to a maximum of about 3,000 feet in the valley trough. The deposits on the east side of the valley are divided into three stratigraphic units; continental deposits, older alluvium, and younger alluvium. On the west side of the valley, the unconsolidated deposits have not been subdivided in this report (see, however, Inter-Agency Committee on Land Subsidence, 1958) but are grouped as alluvium, undifferentiated. 
In the subsurface the younger alluvium interfingers and (or) grades laterally into the flood-basin deposits and into alluvium, undifferentiated. The older alluvium and continental deposits interfinger and (or) grade laterally into the lacustrine and marsh deposits or into alluvium. In the subsurface the older alluvium and continental deposits are also further subdivided into oxidized and reduced deposits on the basis of environment of deposition.

Unconsolidated deposits, which crop out along the margins of the valley and extend beneath the valley floor, were eroded from the adjacent mountains, then transported by streams and mudflows and deposited in lakes, bogs, or swamps or on alluvial fans. The lithologic and water-bearing characteristics of the deposits are dependent upon several controlling factors which include (I) environment of deposition, (2) the type of rock in the source area, and (3) competence of the streams.

According to Davis and others (1959, p. 58-59), oxidized deposits generally represent subaerial deposition, and reduced deposits generally represent subaqueous deposition. Oxidized deposits are red, yellow, and brown, consist of gravel, sand, silt and clay, and generally have welldeveloped soil profiles. Reduced deposits are blue, green, or gray, calcareous, and generally are finer grained than oxidized deposits, and commonly have a higher organic content than the oxidized deposits. The coarsest grained reduced deposits were probably laid down in a flood plain or deltaic environment bordering lakes and swamps. Because of a high-water table, the sediments have not been exposed to subaerial weathering agents. The finest grained reduced deposits were mapped as flood-basin, lacustrine, and marsh deposits.

Unconsolidated deposits in the study area were derived from two principal source areas. Deposits on the east side of the valley, which are arkosic and micaceous, and underlie all but the southwest corner of the area were derived from the Sierra Nevada. The beds which underlie the large streams draining the Sierra Nevada are coarse grained. The deposits in the southwest corner of the area were eroded from gypsiferous marine shale, sandstone, and volcanic rocks of the Coast Ranges. They generally are finer grained than comparable deposits derived from the Sierra Nevada. Deposits derived from the Coast Ranges and the Sierra Nevada, do not always interfinger beneath the present trough of the San Joaquin Valley, but at certain horizons interfinger in much of the San Joaquin Valley west of the present valley trough, probably due to crustal movements. Because the deposits derived from the Sierra Nevada are of greater hydrologic importance in the Hanford-Visalia area only brief reference will be made to the deposits derived from the Coast Ranges. 


\section{Continental Deposits}

The unit mapped as continental deposits probably is of late Pliocene and early Pleistocene(?) age. These deposits are arkosic and crop out on the east side of the valley (pl. 2) adjacent to the Sierra Nevada near Porterville, in Yokohl and Frazier Valleys, and near Colvin Mountain. They are divided in the subsurface (pls. 4, 5, and 6) on the basis of mode of deposition into (I) oxidized deposits that, in part, overlie and, in part, grade laterally into (2) reduced deposits. Only the oxidized deposits are known to crop out.

The continental deposits, as mapped on plate 2 , are correlated with beds described at a depth of 255-744 feet in test hole 24S/26E-36A2 (Klausing and Lohman, 1964, p. D16). They are also considered equivalent to, and an extension of, a part of the continental deposits mapped by Hilton and others (1963, fig. 3 and p. 44-45) where the oxidized continental. deposits are correlated with their upper fine-grained beds of brown to reddish-brown color, and the reduced continental deposits are correlated with their fine-grained basal beds of greenish-yellow to greenish-blue color. Hilton and others (1963, p. 45) reported a coarse-grained section in the subsurface that has not been identified in this area.

The reduced continental deposits consist of bluish-green beds that extend in the subsurface from the Sierra Nevada beneath the older and younger alluvium to Tulare Lake Bed where they interfinger with lacustrine and marsh deposits (pls. 4 and 6). North of Tulare Lake Bed they extend across the valley trough where they underlie and interfinger with alluvium, undifferentiated from the Coast Ranges (pl. 5). The sediments are moderately permeable, and consist of blue or green micaceous, fine to medium sand, silt, and clay. They contain little or no gravel and were probably deposited in a deltaic or flood-plain environment. The unit is further separated by tongues of the lacustrine and marsh deposits. In the logs of the U.S. Bureau of Reclamation core holes, the beds are described as unweathered and containing abundant calcium carbonate. Slightly brackish water is found in the lower one-third of these deposits and is overlain by fresh water in the upper two-thirds. Water from wells that penetrate the lower one-third generally contains more than $1,000 \mathrm{mg} / 1$ (milligrams per liter) total dissolved solids.

Large supplies of water are pumped from the reduced continental deposits in the southern half of the area near stratford, Guernsey, Corcoran, Tulare, and Tipton. At Tulare Lake Bed those deposits constitute the only aquifer. In T. $22 \mathrm{~S} ., \mathrm{Rs}$. 18-20 E., the deposits are thin where present, and fresh water cannot be obtained from wells in sufficient quantities for agricultural purposes (pls. 4 and 5). North of Goshen, the reduced deposits have not been explored for water because wells of sufficient yield for irrigation can be developed in the overlying beds. According to pump-efficiency test records, wells perforated within reduced deposits generally yield 500 to 2,500 gpm (gallons per minute). 
The oxidized continental deposits are a series of fine-grained arkosic beds that underlie the older and younger alluvium. Throughout most of the eastern part of the area (pl. 7), the oxidized deposits are 200 to 500 feet thick. In Yokohl and Frazier Valleys (pl. I), they form a veneer, not more than a few feet thick.

The oxidized deposits consist mainly of deeply weathered, reddish brown, calcareous, sandy silt and clay. Beds of coarse sand and gravel are rare, but where present they commonly contain much silt and clay. Soil types, such as the Porterville and Hovey series (Storie and others, 1940), are well developed on these oxidized deposits. Many cobbles when broken open show weathered aureoles. The highly oxidized character of the deposits is the result of deep and prolonged weathering. Many of the easily weathered minerals, such as hypersthene and feldspar, presumably have altered to clay.

The oxidized continental deposits are poorly permeable but yield water of fair quality. Much of the pumpage between Lindsay and Porterville is from these beds. The yield of wells ranges from 100 to $500 \mathrm{gpm}$. Most wells of comparable depth in the overlying older alluvium and in the interfingering reduced continental deposits, generally have much higher yields.

Lacustrine and Marsh Deposits

The lacustrine and marsh deposits of Pliocene and Pleistocene age consist of blue-green or gray gypsiferous silt, clay, and fine sand that underlie the flood-basin deposits and conformably overlie the marine rocks of late Pliocene age. In the subsurface beneath parts of Tulare Lake Bed these beds extend to about 3,000 feet below land surface. Where the equivalent beds crop out in the Kettleman Hills on the west side of the valley ( 1.2 ), they were named the Tulare Formation by Anderson (1905, p. 181). The lacustrine beds and fossils of the Tulare Formation were mapped and described in detail by Woodring and others (1940, p. 13-26) who considered the top of the Tulare Formation to be the uppermost deformed bed. Therefore, by this definition, all the deformed unconsolidated deposits would form the Tulare Formation. Arnold and Anderson (1910, p. 143-151) considered the blue, green, and gray deposits in the lower part of Tulare Formation in the Kettleman Hills to be estuarine, tidal-marsh and lake sediments. Barbat and Galloway (1934, p. 491) recognized lacustrine beds in the lower and in the upper part of the Kettleman Hills section. According to Woodring and others (1940, p. 14) about 1,700 feet of the Tulare is exposed on the southeast side of North Dome in the Kettleman Hills. Beds equivalent to those mapped as the Tulare Formation by Woodring and others (1940, pl. 3) are shown as lacustrine and marsh deposits in this report (pl. 2). 
In the subsurface, around the margins of Tulare Lake Bed, the lacustrine and marsh deposits form several clay zones that interfinger with more permeable beds of the continental deposits, alluvium, undifferentiated, and older alluvium. Because of contained fossils and stratigraphic relations to adjacent deposits, these clays are considered to be principally of lacustrine origin. Clay zones are generally indicated by characteristic curves on electric logs and thereby facilitate tentative areal correlations between adjacent logs as shown in geologic cross sections. Figure 3 shows the electric log of a core hole that penetrated five of the more significant clay zones shown on the geologic cross sections (pls. 4, 5, and 6) and herein described as the A-clay, B-clay, C-clay, D-clay, and E-clay. The cross sections show a sixth, the F-clay, which is of lesser hydrologic significance. The thick section of lacustrine and marsh deposits beneath Tulare Lake Bed, and the clay zones that extend from it, are aquitards that restrict the vertical and lateral movement of ground water. Clay deposits are nearly impermeable and yield little water to wells and that which is obtained is generally of poor chemical quality.

Plate 8 shows the structure and extent of the A-clay, B-clay, C-clay, D-clay, E-clay, and F-clay. Additional clay zones occur at greater depths; however, they are not differentiated herein. The lowermost of the mapped clay zones is the F-clay.

F-clay.--The F-clay interfingers with the reduced deposits of the older alluvium. It underlies the area southwest of Corcoran and Lemoore, within the limits of the present lake basin. Electric logs on plates 4, 5, and 6 show that it contains a few thin interfingering beds of sand. Plate 8 shows the most prominent structural features are the southward plunging synclines and anticlines. Warping of the clay beds has formed a structural basin several miles west of Corcoran.

E-clay (in part equivalent to the Corcoran Clay Member of the Tulare Formation).--The dark greenish blue-gray, silty, diatomaceous E-clay of Pleistocene age occurs about 60 to 120 feet above the F-clay. It is one of the largest confining bodies in the area and underlies about 1,000 square miles west of U.S. Highway 99 (pl. 8). The beds were deposited in a lake that occupied the San Joaquin Valley trough and which varied from 10 to 40 miles in width and was more than 200 miles in length (Davis and others, 1959, p. 76-81). The first wide-scale correlation of the Corcoran was made by Frink and Kues (1954).

The E-clay extends from Tulare Lake Bed to U.S. Highway 99 and is vertically bifurcated near Goshen (18S/23E-12HI, pl. 6). It is about 140 feet thick near Corcoran (22S/23E-5NI, pl. 4) and the average thickness is about 75 feet. The deposits near Corcoran are probably the thickest section in the San Joaquin Valley (Frink and Kues, 1954, fig. 2). Plate 8 shows that warping has superimposed similar structural features upon the E-clay and upon the F-clay. Fossil assemblages from cores indicate the diatomaceous clay "to be of probable late Pliocene age" (Davis and others, 1959, p. 77-78). 


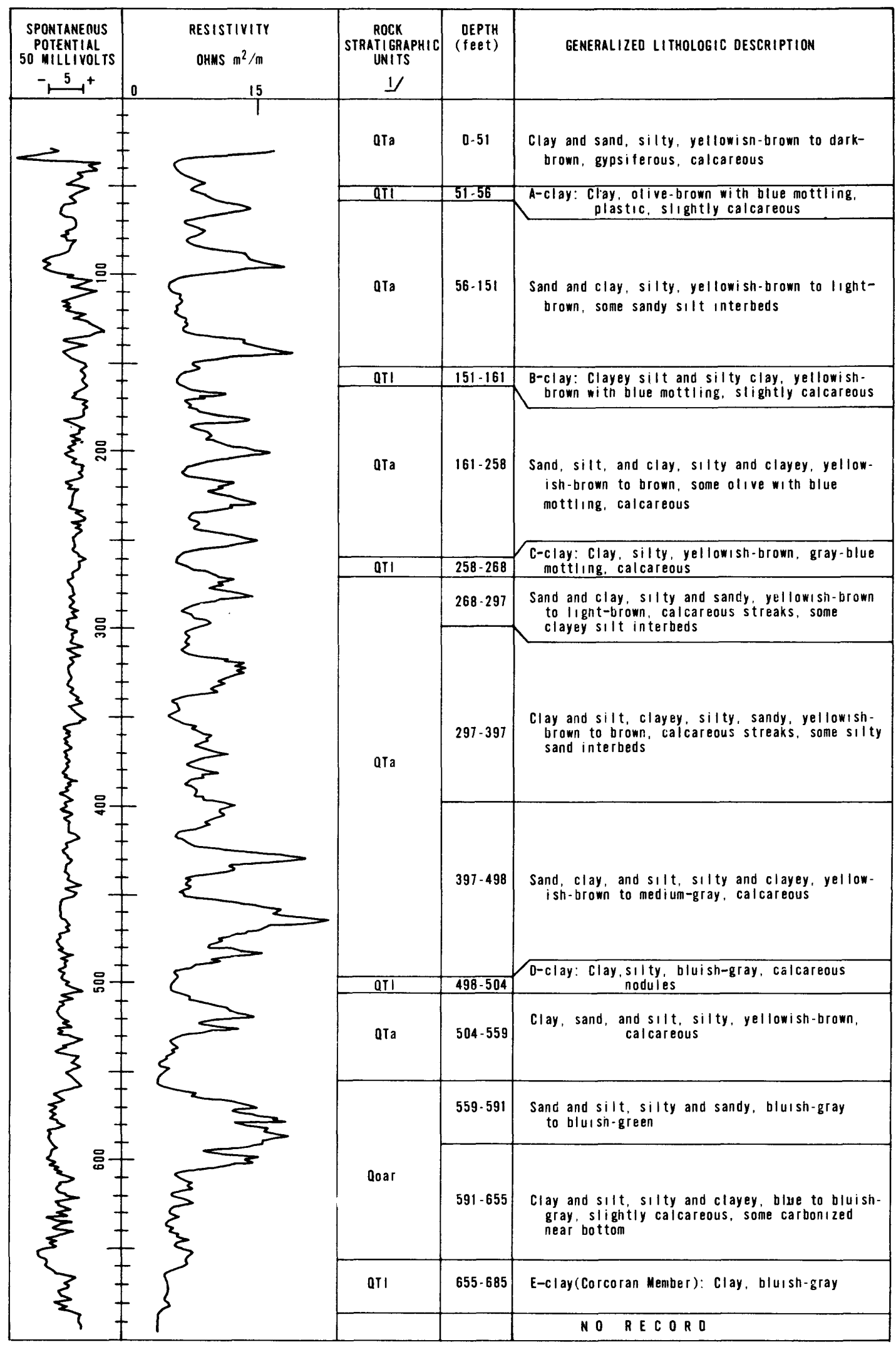

1. For explanation of symbols see plate 4

U.S. Bureau of Reclamation core hole 
According to Bull (1964, p. 5): "Potassium-argon dating, by G. B. Dalrymple, of a volcanic ash associated with the Corcoran permits a reassignment of the age for the Tulare Formation, which has been considered of Pliocene and Pleistocene(?) age. Pumice pebbles exposed near Friant in eastern Fresno County, which are correlated with volcanic ash immediately overlying the Corcoran, contain sanidine crystals that were dated at $600,000 \pm 20,000$ years." Charles Hall of the U.S. Bureau of Reclamation (1965, p. 142-145), discovered vertebrate remains in the Corcoran exposed by the San Luis Canal excavation, about 15 miles northwest of Mendota. The fauna, according to Dr. John Mawby, University of California at Berkeley, is probably of middle Pleistocene (Irvingtonian) or late Pleistocene

(Rancholabrean) age. On the basis of dating the thin beds of volcanic ash by correlation with the 600,000 year-old pumice beds near Friant, paleontological evidence, and the stratigraphic relation, the E-clay is, in this report, considered Pleistocene in age.

D-clay.-The D-clay occurs 60 to 190 feet above the Corcoran Clay Member of the Tulare Formation. This clay zone was mapped in a narrow belt, which extends from Lemoore to Corcoran (p1.8). The clay tongue ranges from 5 to 20 feet thick. About 3 miles south of stratford, the zone merges with the thick section of lacustrine and marsh deposits.

C-clay.--The C-clay which occurs about 140 to 210 feet above the D-clay (section $\mathrm{B}^{\prime} \mathrm{B}^{\prime}, \mathrm{p}$. . 5) interfingers with the older alluvium from stratford and Corcoran on the south, to Riverdale on the north. The clay occurs about 250 feet below land surface, probably extends east as far as Hanford (pl. 8), and underlies about 300 square miles. The thickness of the tongue ranges from about 10 feet near Riverdale to about 100 feet near Corcoran and averages about 30 feet. Warping of the C-clay has formed troughs and shelves that are nearly identical in position to the troughs and shelves in the D-, $\mathrm{E}-$, and F-clays. However, the intensity of deformation is less than the deformation in the lower tongues.

B-clay.--The B-clay is about 140 feet below land surface. It interfingers laterally with the older alluvium. Its areal extent is about the same as the D-clay, as it was mapped in a belt that extends from Tulare Lake Bed to Corcoran and Lemoore (p1. 8). The tongue is about 15 feet thick. The structure contour map indicates that the B-clay was not affected by the forces that warped the lower tongues.

A-clay.--The A-clay, which is shown in section $B-B^{\prime}$ (pl. 5) as underlying the younger alluvium, is the uppermost of the clay tongues. It occurs 40 to 50 feet below land surface and underlies about 300 square miles of the area (pl.8). Although electric logs were not available in the area southwest of Hanford, the presence of the clay is indicated by water levels in shallow wells. The thickness of the tongue ranges from 20 to 50 feet. Forces that warped the tongues below the B-clay apparently did not warp the A-clay. 


\author{
Alluvium, Undifferentiated
}

Alluvium, undifferentiated, derived from the Coast Ranges, crops out along a narrow belt between the Kettleman Hills and Tulare Lake Bed. The formation unconformably overlies the folded lacustrine and marsh deposits in the Kettleman Hills. The deposits are composed of oxidized, poorly sorted, lenticular, gypsiferous clay, silt, sand, and gravel. They are loosely consolidated, and locally contain well-developed soil profiles. Because of the stratigraphic position of the deposits, the alluvium, undifferentiated, is considered late Pliocene to Recent in age. Because of their small areal extent, the deposits are of little significance hydrologically and are not further subdivided. They also are not shown in table 1 which is restricted to depicting deposits principally derived from the Sierra Nevada.

\title{
Older Alluvium
}

The older alluvium is a feldspathic blanket of gravel, sand, and silty sand that overlies the continental deposits from the Sierra Nevada to the valley trough. The unit is probably largely of Pleistocene age although locally the uppermost part may be Recent. The deposits are exposed in large interfan areas north of Ivanhoe, south of Portervilie, and between the channels of the Kaweah and Tule Rivers at Lindsay (pl. 2). Exposures also occur on the floors and slopes of Cottonwood Creek, Yokohl, and Frazier Valleys, and between the Kings River and Cross Creek near Hanford. The older alluvium was derived mainly from the Sierra Nevada and has been divided in the subsurface into (1) oxidized and (2) reduced deposits as described in the following section. Electric logs (pls. 4, 5, 6 , and 7) indicate that the older alluvium is generally coarser than the underlying continental deposits. However, in some logs the chosen contact between the reduced older alluvium and the continental deposits is arbitrary. Only oxidized older alluvium is known to crop out.

The older alluvium is correlated with beds described from land surface to a depth of 255 feet in test hole 24S/26E-36A2 (Klausing and Lohman, 1964, p. D16). The formation is considered to be an extension of the older alluvium mapped on the surface by Hilton and others (1963), because of the similarity of the soil series developed on the unit. 
Reduced older alluvium.--The reduced older alluvium is a moderately permeable arkosic deposit that is not exposed in the area. It overlies the reduced continental deposits (pls. 4 and 6), interfingers with lacustrine and marsh deposits beneath Tulare Lake Bed, and interfingers with alluvium, undifferentiated, north of Tulare Lake Bed (pl. 6). Around the margin of Tulare Lake Bed, the reduced older alluvium intercalates with lacustrine deposits. Near the town of Corcoran, a tongue about 200 feet thick occurs between the C-and E-clays (p1. 4). That tongue, and the deposits below the E-clay, are the major aquifers in that area. Between Riverdale and stratfor numerous tongues of older alluvium ( $\mathrm{pl} .5$ ) form the main aquifers.

Mollusks obtained from a depth of 600 to 602 feet in a core hole, in

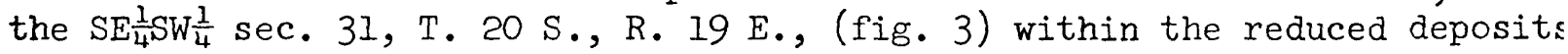
about 50 feet above the Corcoran were examined by $D$. W. Taylor of the Geological Survey. The following forms, of Pleistocene age, were identifiec

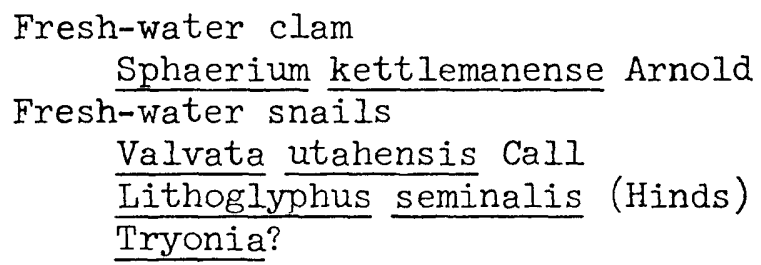

According to Taylor (1966, p. 48), "this assemblage is different from those known previously from stratigraphically lower parts of the Tulare Formation. Sphaerium kettlemanense is known from the basal part of the formation, but none of the other have been found in the Tulare previously. Lithoglyphus seminalis lives in the Sacramento River, but has not been knowr as a fossil. Valvata utahensis is known as a Pleistocene fossil from western Nevada, southeastern California, and the northern borders of the Great Basin."

The reduced older alluvium consist mainly of fine to coarse sand, silty sand, and clay that were probably deposited in a flood plain or deltaic environment. Gravel which occurs in the oxidized older alluvium is generally absent. The deposits are sporadically cemented with calcium carbonate, according to logs of core holes made by geologists of the Bureau of Reclamation. However, those descriptions imply that the calcium carbonate is probably less abundant than in the underlying reduced continental deposits.

Pump-efficiency tests suggest that the reduced older alluvium is moderately permeable. Wells less than 500 feet in depth generally yield 200 to $1,500 \mathrm{gpm}$. 
Oxidized older alluvium--The oxidized older alluvium unconformably overlies the continental deposits. The beds consist of fine to very coarse sand, gravel, silt, and clay derived, for the most part, from granitic rocks of the Sierra Nevada. Beneath the channels of the Kaweah, Tule, and Kings Rivers, electric logs indicate that the beds are very coarse (pl. 7). In the interfan areas, metamorphic rocks and older sedimentary units locally contributed to the deposits and in those areas the beds are probably not as coarse a.s the beds beneath the Kaweah, Tule, and Kings Rivers. Fine-grained deposits occur in the channel of Cross Creek (p1.6), $18 \mathrm{~S} / 22 \mathrm{E}-36 \mathrm{PI}$ ).

An exposure of the oxidized older alluvium in a gravel pit half a mile southwest of Ivanhoe in sec. 11, T. $18 \mathrm{~S} ., \mathrm{R} .25 \mathrm{E}$. consists of about 25 feet of reddish-mottled, well-sorted, fine to very coarse, pebbly sand. Structural features, such as channel cutting and filling, ripple marks and crossbedding, are easily distinguished and indicate a fluviatile origin. The subsurface lithology of the unit is shown by a Bureau of Reclamation core hole (pl. 7 and fig. 4). In general, the beds of sand are thicker and are composed of coarser and more permeable sand than the underlying continental deposits. Also, calcareous nodules and stringers are not as abundant as in the continental deposits.

Most of the soils that occur on the oxidized older alluvium, such as the San Joaquin, Exeter, and Madera series (Storie and others, 1940) are mature and are underlain by a heavy clay subsoil and hardpan at a depth of 1 to 4 feet. The topography developed on the unit is gently undulating and is marked by small mounds and depressions which are locally referred to as "hogwallows." Following heavy rain, water commonly stands in the - depressions for weeks because the clay subsoil and hardpan restrict

percolation. On the upper parts of the Kaweah, Tule, and Kings River alluvial fans above 300 feet in altitude, the soils are yellow, orange, red, or reddish brown and free of alkali. Below 300 feet in altitude the soils on the deposits are alkaline. Near Lindsay, Cairns Corner, and Cross Creek, the soils have a high salt content, but data are insufficient to determine if this condition occurs at depth.

East of U.S. Highway 99, the contact of the older alluvium with the underlying, oxidized continental deposits is well defined in electric logs (pls. 4, 6, and 7). Structure contours, based on electric-log data, (pl. 9) show the altitude above or below sea level of the base of the unit. The older alluvium thickens irregularly from east to west, and probably has filled gorges cut by the ancient Tule River in the underlying oxidized continental deposits near Porterville. The base of the deposits occurs 195 feet below land surface near Exeter, and declines to 430 feet below land surface near Visalia and Goshen. In the log of 18S/23E-12HI (pl. 6) the base of the older alluvium occurs about 200 feet beneath the diatomaceous E-clay. From well 18S/23E-12HI the base of the older alluvium is projected to include the coarse reduced deposits in wells 21S/24E-35MI and 19S/22E-4L (pl. 6), and a similar projection is shown on plate 4.

Throughout its extent, the oxidized older alluvium is generally highly permeable and is a major aquifer. Pump-efficiency tests indicate many wells 200 to 400 feet in depth yield 2,000 gpm. 


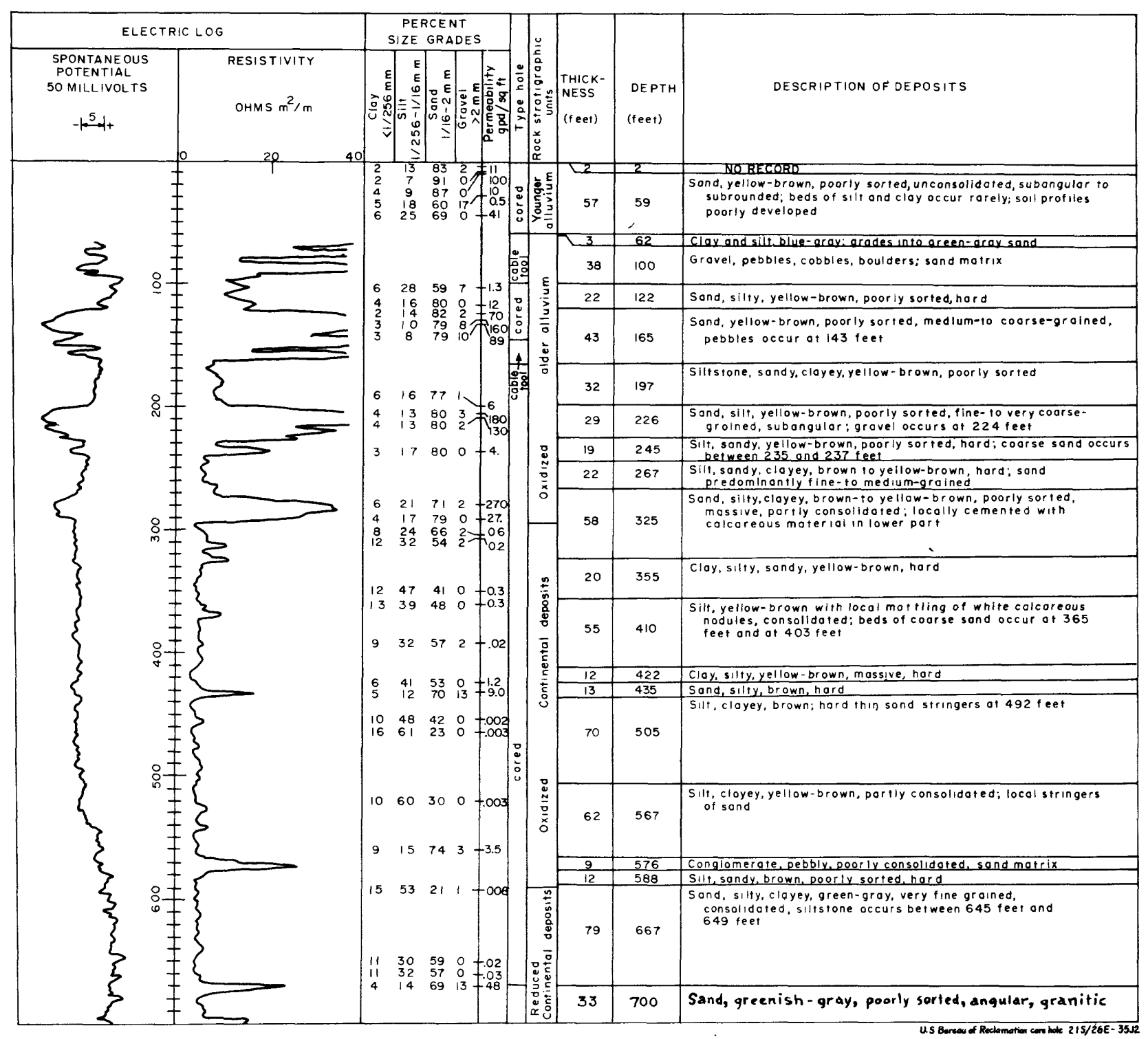

FIGURE 4, -- Log of core hole 21S/26E-35J2. 
Younger Alluvium

The younger alluvium is a veneer of fluvial arkosic beds unconformably overlying the continental deposits and older alluvium (pl. 2). The unit occurs along river bottoms and stream channels, and as shoulders within river trenches (pl. 2). Where the channels become shallow or disappear, the deposits spread laterally as broad flood plains. The lower parts of the fans have well-defined natural levees along channels and sloughs. The younger alluvium represents the latest depositional cycle and at the surface, at least, is Recent in age.

The younger alluvium consists of fluvial, gravelly sand, silty sand, silt, and clay (fig. 4). In most areas, sand is probably not as coarse grained as in the underlying oxidized older alluvium. The soils on the unit, such as the Hanford, Visalia, and Foster series (Storie and others, 1940) are black or dark brown, highly fertile, and show little, or no soilprofile development. The soils are free of underlying clay subsoil and hardpan. The percolation rates through the soil and the underlying deposits are moderate to high. Drillers' logs describe blue or gray deposits on the toe of the alluvial fans, generally south of a line between Lemoore, Guernsey, and Corcoran. Because the younger alluvium in some areas is similar to the older alluvium, the mapped contacts are necessarily arbitrary.

The younger alluvium is thin over most of the area. Thin hardpan and buried soil horizons, which probably occur at the top of the underlying older alluvium, were recorded between Tipton, Corcoran, and Hanford in shallow cores at depths of 7 to 20 feet. At Visalia, reddish deposits and a thin hardpan layer, which is probably the top of the older alluvium, were observed in excavations at depths of about 25 feet below land surface. The younger alluvium, on the Tule River fan, is about 55 feet thick (fig. 4). In the Hanford-Lemoore area, the younger alluvium is about 40 feet thick and is a major water-producing horizon. According to pumpefficiency tests, wells presumably perforated in these deposits yield only 100 to $700 \mathrm{gpm}$. Elsewhere, the younger alluvium is generally above the saturated zone, but serves as a conduit for recharge to water bodies in the underlying geologic units.

Flood-Basin Deposits

Flood-basin deposits include those reduced fine-grained fossiliferous materials underlying Tulare Lake Bed, overflow lands, and slough areas in the valley trough. They are composed mainly of gray, fossiliferous clay, silt, and fine sand, and overlie the fine-grained lacustrine and marsh deposits (pl. 4). The flood-basin deposits are considered Recent in age, and interfinger with both the younger alluvium and alluvium, undifferentiated. Flood-basin deposits are less than 50 feet thick. 
Permeability of Water-Bearing Deposits

The relative permeabilities of fresh water-bearing deposits may be compared by their yield factors. As defined by Poland (1959, p. 32), the yield factor is "... an approximate relative measure for the permeability of the water-bearing material tapped by a well." The yield factor, as used by Olmsted and Davis (1961, p. 139), is equal to 100 times the specific capacity divided by the thickness of saturated material penetrated by a well. Specific capacity of a pumping well is calculated as the discharge in gallons per minute divided by drawdown in feet. Thomasson and others (1960, p. 221-222) show an empirical relation between the coefficient of transmissibility and specific capacity whereby the approximate transmissibility in gallons per day per foot is equal on the average to the specific capacity multiplied by 1,700 .

Five minute pump-efficiency test data supplied by the Pacific Gas and Electric Co. and the Southern California Edison Co. were analyzed and yield factors were computed for wells drawing water from selected deposits. The test procedure used by the Pacific Gas and Electric Co. and Southern California Edison Co. has been standardized sufficiently so that comparisons of yield factors of wells in their respective service areas are considered valid. Thomasson and others (1960, p. 220-221) have noted that differences in yield factors for individual wells are not always significant, due to variations in perforated intervals, well construction, and development. However, systematic variations in these quantities as related to depth and areal distribution probably reflect actual differences in transmissibility and permeability of the materials.

An aquifer test was made at well 20S/19E-25Q1, about 2 miles southwest of Stratford. The pumped well is perforated below the F-clay in the zone from 1,018 to 2,023 feet below land surface. The coefficient of transmissibility was about 70,000 gpd (gallons per day) per foot and the specific capacity and yield factor were 90 and 9 , respectively. This test does not verify the empirical constant, 1,700, previously mentioned. Disagreement is attributed to the possibility that the test was made in a leaky aquifer and to gas and sand pumped with the water during the test.

Yield factors were calculated for the major fresh water-bearing deposits for which data are available. The generalized results of these calculations are presented on plate 10.

The oxidized continental deposits are the least permeable water-bearing deposits in the study area (pl. 10). The average yield factor for these deposits is 3.7. The coefficient of permeability, determined by the U.S. Bureau of Reclamation for 11 laboratory samples, mostly from silty beds, was less than 1 gallon per day per square foot. In a few sandy beds the permeability coefficient ranged from 1.2 to 9.0 gallons per day per square foot. Irrigation wells perforated in these deposits yield 100 to $500 \mathrm{gpm}$. 
Yield factors of the reduced continental deposits between U.S. Highway 99 and Tulare Lake Bed, ranged from 8 to 19 (pl. 10). Yield factors determined from wells beneath Tulare Lake Bed average 4.3. The yields from irrigation wells in these deposits ranged from about 500 to $1,500 \mathrm{gpm}$.

The oxidized older alluvium is more permeable than the underlying oxidized continental deposits as shown by yield factors on plate 10. On the mid and upper parts of the alluvial fans of the Kaweah, Tule, and Kings Rivers and in the interfan areas, yield factors averaged about 43 and yield from wells ranged from 200 to 2,000 gpm. Electric logs of the deposits in the interfan areas suggest the beds are not as permeable as those beneath the channels of the Kaweah and Tule Rivers, but this relation could not be confirmed on the basis of yield factors. Near Traver the yield factors averaged 130. Laboratory determination of the coefficient of permeability by the U.S. Bureau of Reclamation of fine to coarse samples from these deposits ranged from 1.3 to 270 gpd per square foot.

Yield factors of wells penetrating the reduced older alluvium and contiguous lacustrine deposits, averaged about 14 (pl. 10). These values were lower than those in the oxidized older alluvium. This is attributed to prevalence of finer grained materials in the reduced deposits and to more extensive calcium carbonate cementation. Yield of wells in these deposits ranged from 300 to $1,500 \mathrm{gpm}$.

The younger alluvium is generally unsaturated except where it overlies the A-clay near Hanford and Lemoore. Where the beds are saturated, the yield factors averaged about 125; however, there is some question about the accuracy of this figure because depth data for the shallow wells was not complete. The coefficient of permeability determined from samples taken from the core of well 21S/26E-35J2 (fig. 4) on the Tule River fan, by the U.S. Bureau of Reclamation, ranged from 0.5 to 100 gpd per square foot. Maximal yield of wells in the younger alluvium is about $700 \mathrm{gpm}$. 


\section{HYDROLOGY}

This discussion of the hydrology of the Hanford-Visalia area includes a brief resume of the available water supply, a description of ground-water occurrence, and discussion of hydrologic conditions by subarea.

\section{Water Supply}

The present water supply of the Hanford-Visalia area is obtained from precipitation, streamflow, canal imports, and ground water. Precipitation on the area occurs chiefly as rain, although the adjacent areas at high altitudes in the Sierra Nevada receive considerable snow. Streams tributary to the Hanford-Visalia area include the Kings, Kaweah, and Tule Rivers which are perennial, and Cottonwood, Yokohl, and Frazier Creeks which are intermittent. Almost all the flow from streams is diverted into a network of distribution canals and is used for irrigation. Excess uncontrolled floodwaters discharge onto Tulare Lake Bed.

Canal deliveries by the U.S. Bureau of Reclamation supplement the local stream and ground-water supplies. In the latter part of 1949, the U.S. Bureau of Reclamation began importing water from the San Joaquin River to the southern part of the San Joaquin Valley, via the Friant-Kern Canal, which traverses the east border of the valley (pl. 12). Within the HanfordVisalia area, ten irrigation districts have long-term contracts for water delivery during the growing season. Additional irrigation districts in the report area receive water only when a surplus is available.

Most of the Hanford-Visalia area relies principally on ground water pumped from wells either as a supplement or as the only source of water for irrigation, domestic, and industrial uses.

\section{Ground-Water Conditions}

Ground-water conditions in the San Joaquin Valley have altered greatly since the reconnaissance study by Mendenhall and others (1916). At that time the water levels in wells generally were less than 20 feet below land surface on the alluvial fans of the Kaweah, Tule, and Kings Rivers, and flowing wells were common west of Goshen and Tulare (Mendenhall and others, $1916, \mathrm{pl} .1)$. Annual ground-water pumpage in the San Joaquin Valley was estimated to be a quarter of a million acre-feet. Ground-water pumpage increased after World War I, causing water levels to decline and wells to cease flowing. The lower water levels in some areas became a serious problem and a study by Harding (1927), noted the general relation between water-level fluctuations, pumpage, and recharge. Water-level decline accelerated after World War II as increased development required much greater quantities of ground water. By 1955, pumpage in the San Joaquin Valley had increased to 9 million acre-feet. Davis and others (1959 made a 
reconnaissance study of ground-water conditions in the San Joaquin Valley and showed that in the east-central part of the valley, north of the Kaweah River, the water supply generally was in balance with demand. The same study showed that south of the Kaweah River, surface-water supplies were generally inadequate, and overdraft on ground-water supplies was widespread. The year by year decline in water levels continued except where surface water, supplied by the Friant-Kern Canal, has reversed the trend.

Ground water in general, and specifically in this report area, occurs in several circumstances. Water-bearing deposits, or aquifers, may be unconfined (water table) or confined (artesian). In a water-table aquifer, water levels are at the top of the zone of saturation where hydrostatic pressure is equal to atmospheric pressure. In a confined aquifer, the aquifer material entirely saturated, is overlain by material of low permeability, and the water saturating the aquifer is under pressure. The pressure surface, or piezometric surface, in such an aquifer is indicated by the height to which water will rise in a well tapping the aquifer and is always above the top of the aquifer. Because alluvial deposits are heterogeneous in composition, perfect examples of either unconfined or confined aquifers are rare although many may approximate these conditions. Aquifers that seem to be unconfined may react to stresses of short duration, such as loading on the aquifer or fluctuations in pressure due to pumping, in much the same manner as confined aquifers. These are referred to as semiconfined aquifers, implying that they respond to pressure changes over short periods of time, but that the head adjusts to equilibrium with the water table over long, low-stress periods of time.

The ultimate source of recharge to ground water is precipitation, either as rain or snow. This is true whether precipitation falls directly on the land surface of a given area, flows into the area in the natural channels of rivers and streams, or is artifically diverted through canals and irrigation systems. A secondary source of recharge is water pumped from the ground and allowed to seep back after use for irrigation or other purposes. This in effect is a cyclical use of ground water and may affect the chemical quality of the returned water.

\section{Aquifer System}

The aquifer system of the Hanford-Visalia area consists of all the water-yielding deposits in the area. It contains ground water under unconfined, semiconfined, and confined conditions in the study area. In general, aquifers in the younger alluvium, the flood-basin deposits, and in the oxidized older alluvium are unconfined, and semiconfined in the reduced older alluvium and the oxidized and reduced continental deposits. Confined aquifers in the reduced continental deposits and reduced older alluvium are found below and between the nearly impermeable lacustrine clays in the vicinity of Tulare Lake Bed. These aquifers contain fresh ground water. Although they are part of a single contiguous zone of saturated material, records of water-level fluctuations indicate that each of the three types of aquifers function independently of the others. 
Plate 11, constructed from water-level measurements in about 1,500 wells, shows the configuration of the water table and piezometric surfaces of the major unconfined, semiconfined, and confined aquifers during autumn 1961 and winter 1962, the nonpumping season. Between the Sierra Nevada and the Atchison, Topeka and Santa Fe Railway, water in the unconfined and semiconfined aquifers has a generally southwesterly sloping gradient. West of the railroad, water levels in wells indicate at least three well-defined aquifer systems: (1) Above the A-clay, unconfined; (2) beneath the A-clay and above the C-clay, confined; and (3) beneath the E-clay, confined. The water level in the shallowest aquifer, the deposits above the A-clay, is in some areas less than 10 feet below land surface. Wells perforated beneath the A-clay and above the C-clay have water levels 50 to 75 feet lower than water levels in wells that are perforated exclusively above the A-clay. The water level in the deposits beneath the E-clay is in some areas more than 300 feet below land surface. Data were not available to construct piezometric maps of all the confined aquifers in this area nor the full extent of the piezometric surface of any particular part of the system.

Unconfined and semiconfined.--Ground water is unconfined in the oxidized older alluvium, younger alluvium, and in the flood-basin deposits. Semiconfined ground water is found in the oxidized continental deposits and in both the oxidized and reduced older alluvium. A clear distinction between the unconfined and semiconfined aquifers is not always evident because during the nonpumping season water levels in wells in semiconfined aquifers tend to recover to the same level as that in unconfined aquifers. Figure 5 shows hydrographs of wells penetrating both aquifers. Hydrographs of wells individually penetrating only unconfined or semiconfined aquifers indicate that head differentials between these units are induced by pumping during the irrigation season.

The Kaweah, Tule, and Kings Rivers, several intermittent streams, and the Friant-Kern Canal, provide the principal surface-water supplies for irrigation in the Hanford-Visalia area. Seepage of water from rivers, streams, irrigation canals and ditches, and irrigation water applied in excess of plant and soil-moisture requirements, constitute the principal sources of water infiltrating to the unconfined and semiconfined aquifers. Artificial recharge and direct precipitation contribute minor quantities of water to these aquifers. The principal source of water in the younger alluvium above the A-clay is seepage from the Last Chance Ditch, Lemoore Canal, and from irrigation return.

Ground water moves from points of high head toward points of low head along paths generally normal to contour lines on a water-level map, just as surface water flows downhill in a streambed. Plate 11 shows that ground water in the unconfined and semiconfined aquifers is moving southwestward toward Tulare Lake Bed, generally paralleling the slope of the land surface. The rate of ground-water movement is directly proportional to the hydraulic gradient and to the transmissibility of the aquifer materials. Where distribution of recharge and discharge is irregular, the transmissibility of sediments influences the hydraulic gradient by restricting movement of water migrating from recharge areas. Thus, when replenishment 


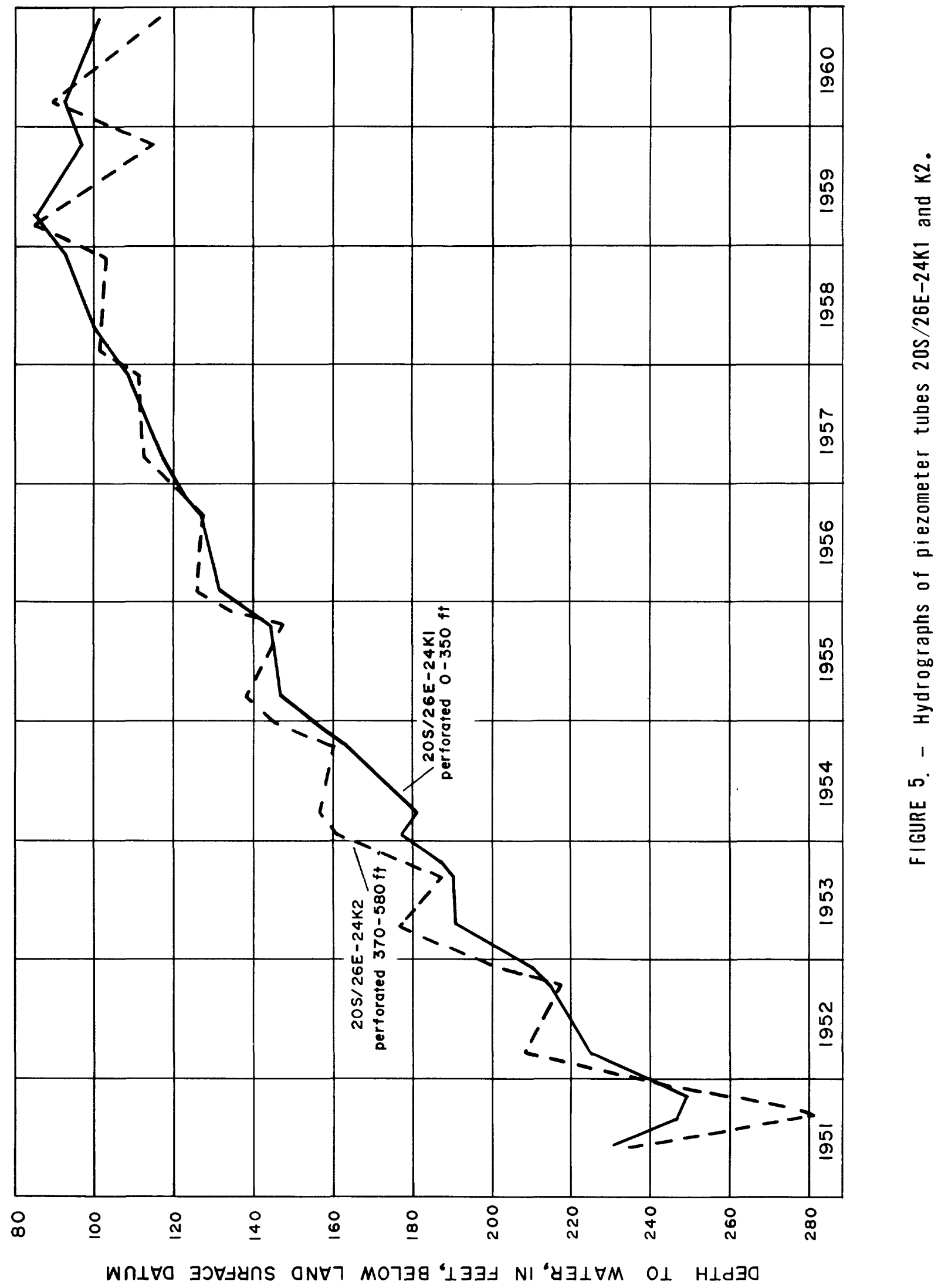


occurs, ground water may build up in mounds under recharge areas. Major recharge areas are indicated by ground-water mounds beneath the Kings River near Hardwick, beneath the Kaweah River near Visalia, and beneath the Tule River near Woodville. Water-level contours also suggest that the Kaweah and Tule Rivers are receiving effluent seepage from alluvium in the river channels east of Porterville and Lemoncove. Areas where ground-water withdrawals exceed recharge are indicated by depressions in the water table west of Lindsay and Ivanhoe.

The relation of water levels and water-level fluctuations in the unconfined and semiconfined aquifers is illustrated by hydrographs of two U.S. Bureau of Reclamation piezometer tubes (fig. 5). These installations and many others in the San Joaquin Valley were constructed by installing two piezometers at different depths in a single hole, each separated from the other by impermeable packers at a selected depth. Piezometer $24 \mathrm{KI}$ is perforated from 0 to 350 feet below land surface in the oxidized older alluvium, whereas, $24 \mathrm{~K} 2$ is perforated from 370 to 580 feet in the oxidized continental deposits. The hydrographs of these two piezometers (fig. 5) show that during heavy pumping seasons, the water level in $24 \mathrm{~K} 2$ declined more rapidly than that in $24 \mathrm{KI}$, but during the nonpumping season in the winter months, the water in both piezometers approached the same level. These water-level fluctuations are typical of fluctuations at different depths throughout the unconfined and semiconfined aquifers.

Figure 6 shows the hydrographs of Bureau of Reclamation piezometers 2IS/24E-3IDI, and D2, perforated from 0 to 257 feet below land surface (3IDI) in the oxidized older alluvium, and from 277 to 371 feet (3ID2) in the reduced older alluvium. Well logs at this site show the top of the E-clay about 365 feet below land surface; therefore, piezometer 31D2 should reflect water-level fluctuations in the semiconfined aquifer above the E-clay. During heavy pumping seasons, the water level in 3ID2 declined more rapdily than the water level in $31 D 1$ and during the nonpumping season, the water level in both piezometers approached the same level.

Although not clearly shown by these hydrographs, some degree of confinement is suggested. In general, hydrographs of wells in the oxidized continental deposits and in the reduced older alluvium show greater amplitude of fluctuation under stress, indicating a more nearly confined state than hydrographs of wells tapping the overlying oxidized older alluvium.

Confined.--Davis and others (1959, p. 88) considered the E-clay (in part equivalent to the Corcoran Clay Member of the Tulare Formation) as the principal confining bed in the southern San Joaquin Valley. However, confined ground water occurs in aquifers beneath and between other widespread lacustrine clays (pl. 8) in the western and southwestern part of this report area. Not all of these confined aquifers are indicated on plate ll because scarcity of selectively perforated wells prevented construction of meaningful contours. 


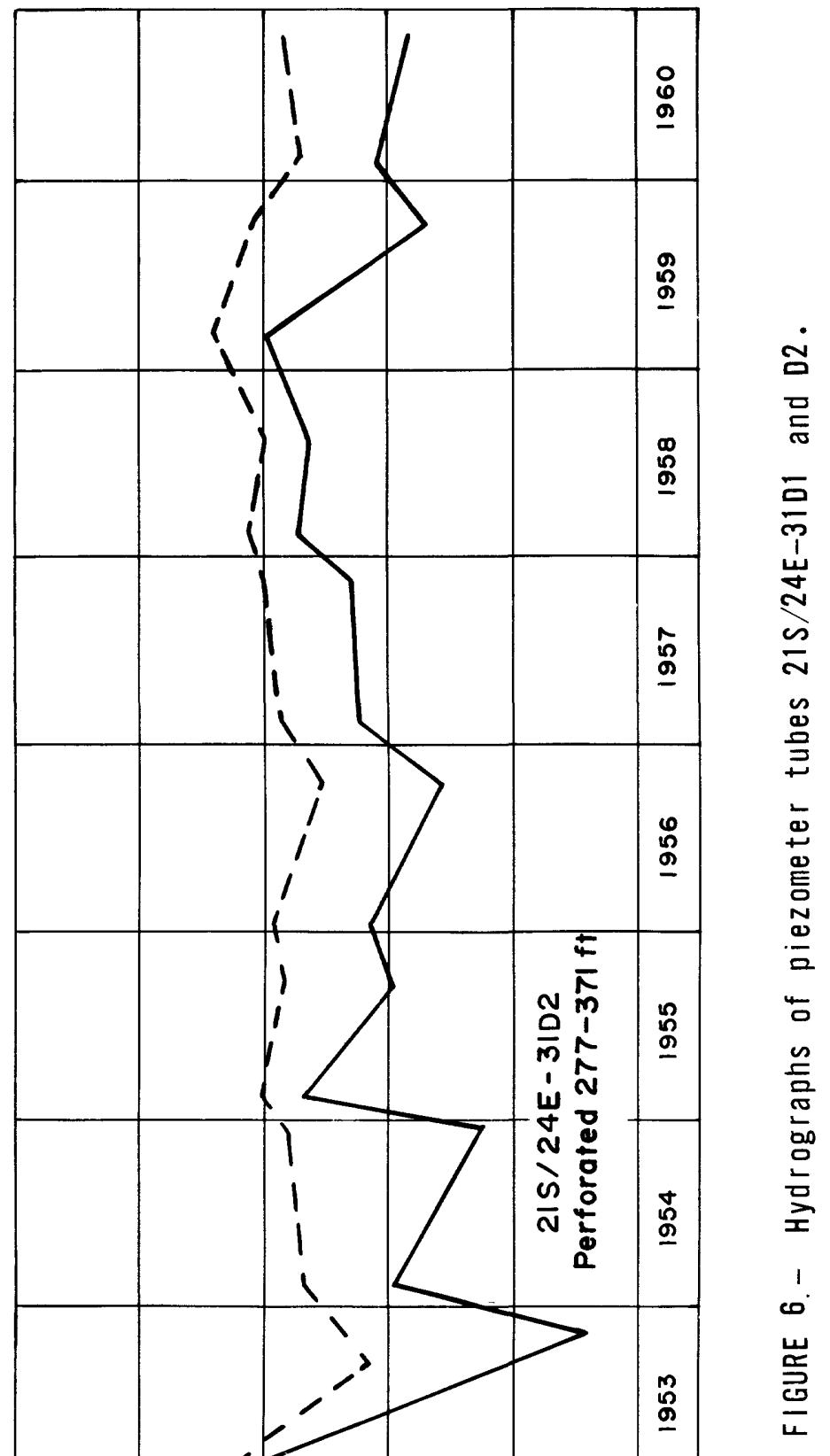


Water-level and piezometric-contour maps were constructed on the basis of well-perforation data compared with structural-contour maps of the lacustrine clays in order to identify wells perforated in common aquifers. Data were sufficient only to construct piezometric contours for the zone beneath the E-clay and the zone between the A-and C-clays where it is not separated by the B-clay. However, wells 2OS/2OE-27DI and 19S/2IE-29RI (pl. 6) show the water level in two of the unmapped zones.

The source of most of the water found in confined aquifers is the unconfined and semiconfined aquifers to the east and northeast. Some of the water in these aquifers undoubtedly is introduced by slow vertical percolation through the confining members. Head differences, explained on the following page, suggest that this is so. Additional vertical movement of water between confined aquifers and overlying beds probably takes place in well casings perforated through more than one aquifer and in gravel packed wells; both types of well construction are common in the area.

Water-level contours shown on plate 11 indicate that ground water in the area moves in a general southwesterly direction from the unconfined and semiconfined aquifers into the confined aquifers beneath and between the lacustrine clays. Water movement in the confined aquifers is in the same general direction. In the aquifer beneath the E-clay, ground water is moving toward a depression in the piezometric surface which is part of a depression mapped by Davis and others (1959, pl. 5).

Water-level fluctuations due to pumping water from any one of the confined aquifers are not necessarily reflected in other aquifers vertically above or below the one being pumped. The hydrograph of well 19S/2lE-9Fl (fig. 7) shows the water level in the unconfined aquifer above the A-clay and the effect on this water level when a well within the same 40-acre tract (19S/2IE-9F2) perforated in the aquifer below the A-clay is pumped. One explanation of these fluctuations is that the water level in $9 F 1$ shows the loading impact as the pump column in $9 \mathrm{~F} 2$ is filled and subsequently emptied, but no other response is observed in the aquifer above the A-clay. Because of extensive pumping of water from confined aquifers, the piezometric head in each of the aquifers confined beneath and between lacustrine clays, has declined to a point below the head in respective overlying aquifers. Water levels in wells perforated between the A-and Cclays are 50 to 75 feet lower than water levels in wells perforated above the A-clay. Water levels in wells perforated below the E-clay (Corcoran) are more than 200 feet lower than those above the A-clay, and are about 125 to 150 feet lower than water levels in wells perforated between the A- and C-clays. 


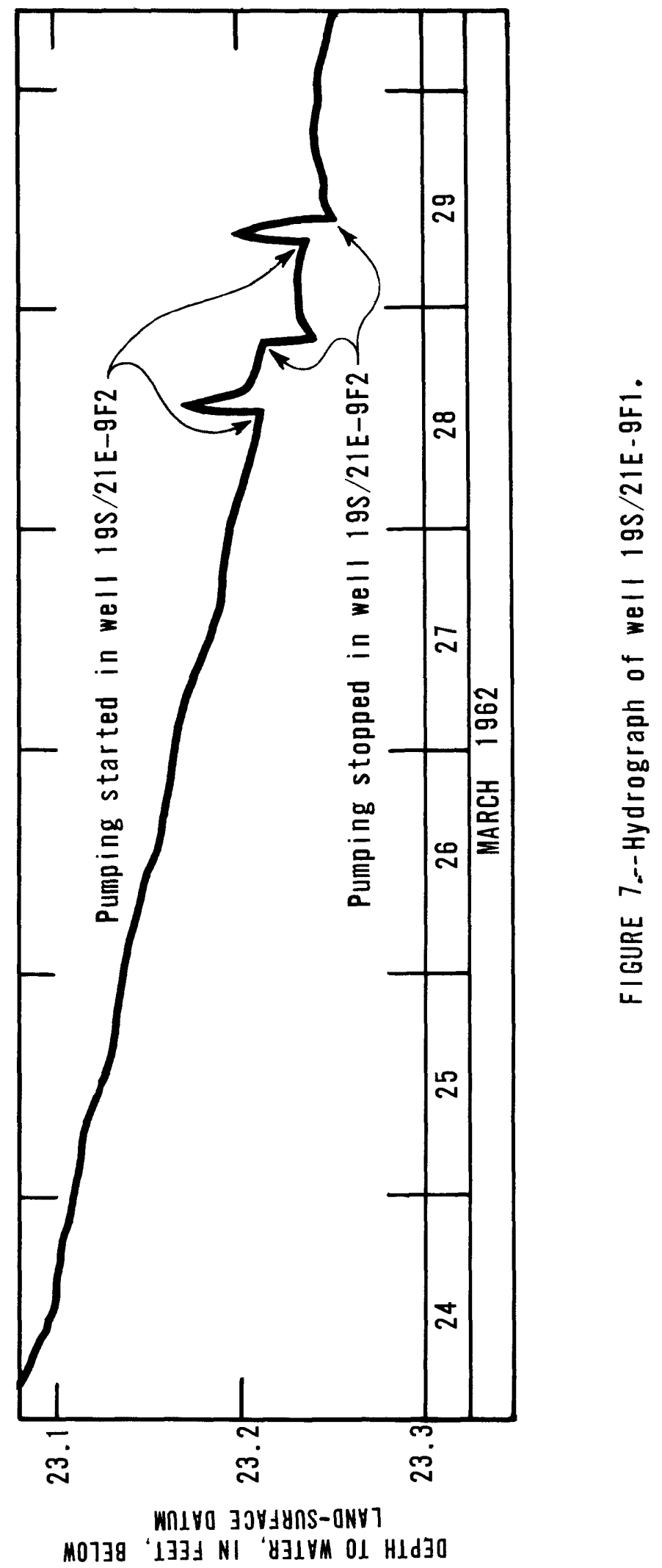




\section{Ground-Water Withdrawals}

A substantial part of the water supply required for irrigation in the study area is obtained from rivers, streams, and canals, and from precipitation. The supply represented by surface water and precipitation is supplemented with ground water in some parts of the area. Elsewhere in the area, a major part of the irrigation supply is from ground water and in several small parts of the area, ground water is the only source of water for irrigation ( $\mathrm{pl}$. 12).

Most of the ground water used for irrigation is pumped by electric power and the balance is from pumps powered by diesel or gasoline engines. Electric-power data, in kilowatt-hours, used by irrigation wells in 1956 and 1960 was obtained from Pacific Gas and Electric Co. and from Southern California Edison Co. for their respective power districts in the report area. Where the power figures included areas outside the report area, the power used inside the area was prorated on a simple area basis. Water pumped for irrigation was calculated by dividing total kilowatt-hours of power consumed by a factor for kilowatt-hours per acre-foot of water pumped, as determined from pump-efficiency tests, and adjusted for total lift. An estimated figure for the quantity of water pumped from wells equipped with diesel and gasoline engines was added to the water pumped by electric power to obtain the total quantity of ground water pumped for irrigation. The quantity of ground water pumped for municipal and domestic use by communities in the area was obtained from municipal records of water pumped from wells when available, and estimated on the basis of population where figures for pumpage could not be obtained. Finally, a quantity of ground water pumped for domestic use and livestock on farms was estimated.

Gross ground-water withdrawal for all purposes in the Hanford-Visalia area is estimated to be 1,240,000 acre-feet for the 1955-56 water year and 2,070,000 acre-feet for the 1959-60 water year (table 2).

Table 2.--Ground-water pumpage in the Hanford-Visalia area

(in acre-feet)

\begin{tabular}{|c|c|c|c|}
\hline Use & : & $1955-56$ & $1959-60$ \\
\hline Irrigation & & $1,210,000$ & $2,030,000$ \\
\hline $\begin{array}{l}\text { Municipal and domestic } \\
\text { (in cities and towns) }\end{array}$ & & 20,000 & 30,000 \\
\hline $\begin{array}{c}\text { Domestic and livestock } \\
\text { (suburban and farms) }\end{array}$ & & 10,000 & 10,000 \\
\hline Total & & $1,240,000$ & $2,070,000$ \\
\hline
\end{tabular}




\section{Hydrologic Conditions by Subareas}

The Hanford-Visalia area is divided into six subareas in this report. Subdivision boundaries, shown on plate 12, represent a compromise between major geologic and hydrologic boundaries, and irrigation district boundaries. They were selected primarily for convenience in determining supplies of surface water delivered or diverted for irrigation. The areas north of Kings River and north of Cross Creek are excluded because hydrologically they are part of a separate study, currently in progress, adjacent to the northern boundary of the Hanford-Visalia area.

The annual amount of precipitation avajlable to crops was calculated as the average of the rainfall records at seven weather stations in or near the report area after half an inch of precipitation for each major storm had been subtracted. One-half inch of precipitation is the approximate amount lost by immediate evaporation (Blaney, 1928, p. 154) and thus would not be available to crops. Precipitation in feet was converted to acre-feet of water by multiplying it by irrigated acreage in each subarea. The area not under irrigation was excluded because it is assumed that all precipitation would be disposed of by evaporation and transpiration.

Evapotranspiration as used herein includes all evaporation and transpiration losses from irrigated acreage. Transpiration, water use by plants during the growing season, makes up the largest part of water consumed in the area. Evaporation is a lesser increment. Total irrigated acreage for each crop was determined from a 1958 land-use survey by the California Department of Water Resources. Water requirements for different crops grown in the San Joaquin Valley have been determined by the State Water Resources Board (1955, tables 13 and 14). Summation of the products of irrigated acreage and unit water requirements is equal to the estimated evapotranspiration. As irrigated acreage increased steadily from 1956 to 1960, the value for evapotranspiration for years prior to 1958 and years following 1958 were prorated according to an estimated rate of increase in irrigated acreage supplied orally by the U.S. Soil

Conservation Service at Hanford and by the Agricultural Extension Service at Visalia.

Ground-water withdrawals, as an increment of irrigation water supply, have been omitted from this part of the discussion because it was not practicable to calculate withdrawal from ground watex by individual subareas.

\section{Tule River Subarea}

The Tule River and Friant-Kern Canal are the principal sources of surface water for irrigation in the Tule River subarea (pl. 12). In addition to surface water, in this area east of Tipton, ground water for irrigation is pumped from unconfined and semiconfined aquifers. Westward from Tipton, ground water is pumped from unconfined and semiconfined aquifers above the E-clay and from the confined aquifer below the E-clay. 
Hydrographs of three wells, selected to show typical water-level fluctuations in the subarea, are shown on plate 12. Two of the wells, 22S/23E-15QI and 2IS/27E-29QI, tap the unconfined aquifer. The third hydrograph, for well 2lS/23E-35BI, shows water-level fluctuations in the confined aquifer beneath the E-clay. During the period from fall 1955 to fall 1960, these hydrographs indicate a general water-level decline of 4 feet in 15QI, 4 feet in 29Q1, and 22 feet in 35BI.

In addition to the hydrographs, plate 12 shows a graph of the cumulative departure from mean yearly runoff of the Tule River as measured at a gaging station near Porterville. This graph generally follows the trend of the hydrographs of wells.

Bar graphs on plate 12 indicate qualitatively, changes in demand for ground water. The graphs show 2 years (1956 and 1958) of water supply in excess of the quantity required to satisfy evapotranspiration, indicating that ground-water withdrawals probably were less than in 1957, 1959, and 1960 when precipitation and surface diversions were not adequate to satisfy evapotranspiration.

In general, water levels, shown by the hydrographs, correlate with the graph showing difference between water supply (excluding ground water) and evapotranspiration. Water levels rise following years of surplus supply and decline following years of deficient supply.

\section{Lindsay Subarea}

Surface watex in the Lindsay subarea ( $\mathrm{pl}$. 12) is obtained from the Kaweah River and from the Friant-Kern Canal. About two-thirds of the imported canal water flows into part of the area east of the railroad connecting Exeter and Strathmore. West of the railroad, irrigation water is supplied, in part, from the Kaweah River and the Friant-Kern Canal, but this area is mainly dependent on ground watex. Ground water in the Lindsay subarea is pumped from semiconfined aquifers in the continental deposits and from the unconfined aquifers in the oxidized older alluvium.

Deliveries of canal water beginning in 1951 had a notable effect on water levels in much of the subarea. Prior to arrival of canal water, water levels in much of the area were 100 to 200 feet below land surface and a large cone of depression was centered about 1 mile southwest of Lindsay (Davis and others, 1959, pl. 15). Water levels in the unconfined and semiconfined aquifers recovered after canal water delivery, as indicated by hydrographs of wells 20S/26E-24KI and K2 (fig. 5) and well 20S/26E-16Al shown on plate 12. The cone of depression migrated westward (pl. 1I), and water levels rose about 140 feet in the area where the cone of depression formerly was centered. 
Hydrographs of wells in the western part of the subarea, 19S/26E-28Dl and 20S/26E-2OPl, show a limited response to delivery of canal water because in this locality water for irrigation is supplied by the Kaweah River and from ground water; however, these two hydrographs correlate better with the bar graphs showing supply (excluding ground water) and evapotranspiration (p1. 12) than those from wells in the eastern part of the subarea where canal deliveries have established a supply more reliable and constant than that from flow in the Kaweah River.

\section{Kaweah River Subarea}

Surface water is supplied to the Kaweah River subarea (p1. 12), from the Kaweah River and from the Friant-Kern Canal. Additional water for irrigation is pumped from unconfined and semiconfined aquifers in the continental deposits and in the oxidized and reduced older alluvium. West of U.S. Highway 99, ground water also is obtained from the confined aquifer in the continental deposits beneath the E-clay.

Figure 8 shows a long-term relation between runoff in the Kaweah River and water-level fluctuations in well 19S/24E-16R and well 19S/25E-10RI. Hydrographs on plate 12 show water-level fluctuations in wells 19S/25E-1ORI, $18 \mathrm{~S} / 25 \mathrm{E}-30 \mathrm{H2}$, and $18 \mathrm{~S} / 23 \mathrm{E}-23 \mathrm{El}$ which tap the unconfined aquifer in the oxidized older alluvium. The hydrograph for well 19S/23E-27Al, probably tapping the semiconfined aquifer in the reduced older alluvium, also is shown.

Bar graphs on plate 12 indicate the relation between precipitation and surface-water supply and evapotranspiration requirements in the Kaweah River subarea. The third bar graph presents the difference between supply and use. Both the supply and difference graphs indicate a general correlation with water-level fluctuations.

\section{Ivanhoe Subarea}

The Kaweah River and the Friant-Kern Canal supply surface water to the Ivanhoe subarea. Deliveries of imported surface water via the canal to the eastern part of the subarea began in 1949.

In the eastern part of the subarea, the water table slopes toward a shallow cone of depression (pl. 1l), which interrupts the general southwest gradient. The depression in the water table is centered in an area that depends on ground water for irrigation (pl. 12). Hydrographs shown on plate 12 demonstrate the éffect of imported water in wells 17S/26E-7RI, in the semiconfined aquifer in the oxidized continental deposits, and $30 \mathrm{El}$, in the unconfined aquifer in the oxidized older alluvium. The hydrograph for well 17S/25E-32RI shows water-level fluctuations in the area where imported surface water is not available. Water-level fluctuations shown on the hydrographs show the effect of imported water, and superimposed fluctuations caused by annual and seasonal variations in water supply and demand. 


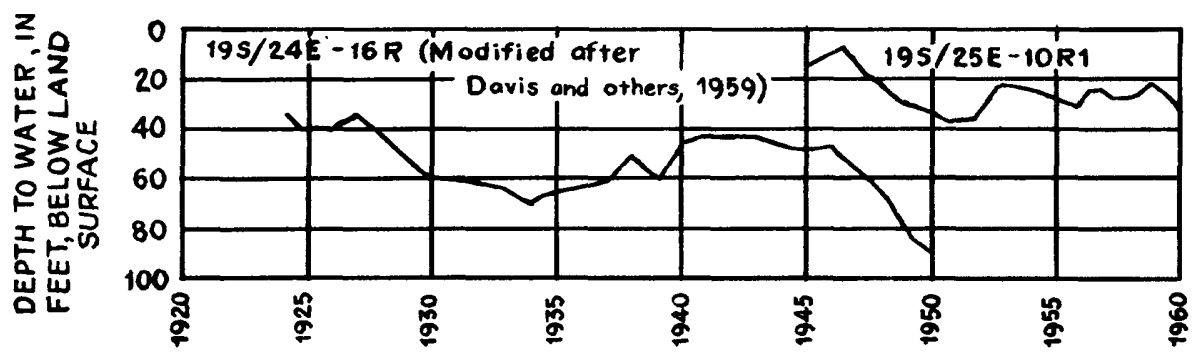

A. Ground-water level near Visalia

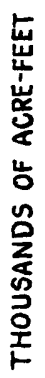

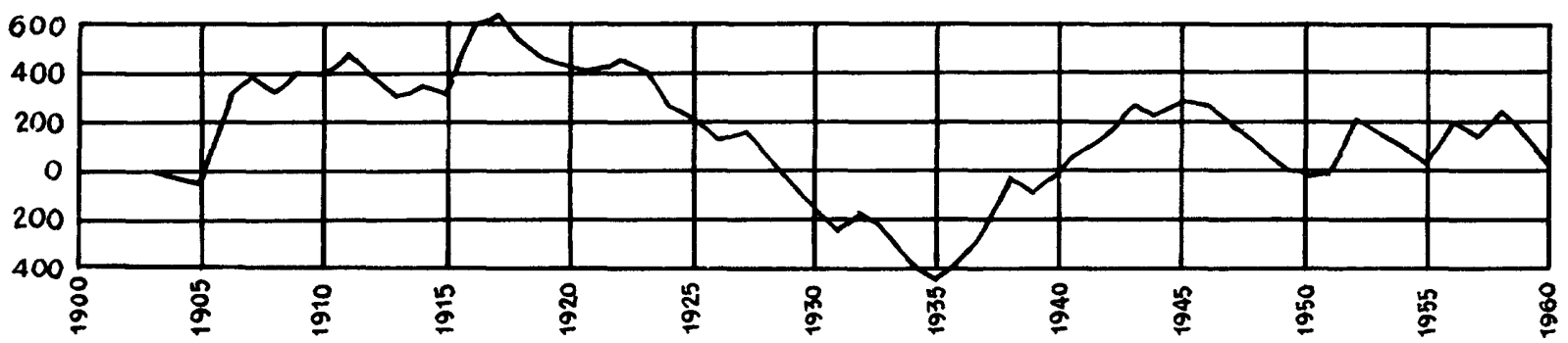

B. Accumulated departure from mean yearly runoff_Kaweah River near Three Rivers, 1904-1960

FIGURE 8.--Representative hydrographs of wells near Visalia and an accumuląted departure curve of the Kawean River. 
Bar graphs on plate 12 indicate a general correlation between the supply graph, the graph showing difference between supply and evapotranspiration, and the hydrographs. This correlation is not clear on the hydrograph of well 17S/25E-32RI where precipitation probably is the only correlative factor. In the area dependent on ground water, precipitation is not distributed seasonally according to crop requirements, consequently, ground water is pumped for irrigation even in years of heavy precipitation. In years when there is little precipitation, ground-water pumpage is increased and some local overdraft may occur.

\section{Kings River Subarea}

Most of the surface-water supply for irrigation in the Kings River subarea is obtained from the Kings River. During wet years, overflow from the Kaweah River enters this subarea through Cross Creek. Surface water imported via the Friant-Kern Canal usually is less than 10 percent of the total surface-water supply.

West of Hanford, ground water is pumped from the unconfined aquifer above the A-clay, and from the confined aquifers between the A-and E-clays. Very few wells in this vicinity have been drilled into the confined aquifer beneath the E-clay. East of Hanford the unconfined and semiconfined aquifers above the E-clay and the confined aquifer below the E-clay all are pumped to supply water for irrigation.

Hydrographs of three wells are shown on plate 12, illustrating waterlevel fluctuations in three parts of the aquifer system in the Kings River subarea. Well 19S/23E-8J1 penetrates the semiconfined aquifer in the reduced older alluvium, well 2OS/21E-3Al is in the unconfined aquifer in the younger alluvium above the A-clay, and well $18 \mathrm{~S} / 20 \mathrm{E}-3 \mathrm{KI}$ is perforated in the confined aquifers between the A-and C-clays.

Bar graphs on plate 12 show the water supply, excluding ground-water pumpage, evapotranspiration requirements, and the surplus or deficiency of supply less evapotranspiration. Water-level fluctuations shown on the hydrographs correlate crudely with the bar graphs. In general, water levels from the semiconfined and confined aquifers provide the best correlations with quality of correlation improving as degree of confinement increases. 
Tulare Lake Subarea

During wet years substantial quantities of surface water are available to the Tulare Lake subarea (pl. 12) from the Kaweah and Tule Rivers. A small quantity of water is imported into this sujarea via the Friant-Kern Canal. In dry years, the subarea is dependent primarily on ground water for irrigation.

Water-level fluctuations in confined aquifers beneath the E- and F-clays are shown by hydrographs of wells 2OS/2IE-16MI and 23Al, located just north of this subarea, on plate 12. The large fluctuations shown are characteristic. of these aquifers where extensive pumping is required and emphasizes the fact that most recharge from irrigation to these aquifers is from a distant source. Vertical recharge from irrigation return by leakage through the fine-grained confining beds is probably very slow.

Surface-water supply and precipitation, evapotranspiration, and difference bar graphs (pl. 12) indicate a general water deficiency in the Tulare Lake subarea. Deficiencies are compensated for by pumping from ground water and these graphs emphasize the dependence of the subarea on ground water for irrigation.

The bar graphs tend to correlate crudely with the hydrographs; however, because of the limited number of control points on the hydrographs the correlation is not clearly apparent.

\section{Summary of Water Supply}

The total surface-water supply including precipitation, water demand for evapotranspiration, and difference between these supply and demand figures are listed in table 3. A deficiency is indicated in 3 of the 5 years of record included here, accruing to a cumulative deficiency for the 5-year period. This deficiency was compensated for by pumping ground water.

The total water supply available to irrigated land in the HanfordVisalia area for 1960 (table 4) is 2,740,000 acre-feet. Evapotranspiration accounts for 1,940,000 acre-feet. This leaves 800,000 acre-feet required to satisfy soil moisture deficiency and infiltration to the water table from river and stream channels, canals, ditches, and artificial-recharge sites, and as irrigation return. Surface-water outflow from the area was deemed negligible.

In 1958 there were about 730,000 acres of irrigated land in the study area. Assuming the same figure for 1960, the water supply for irrigation in 1960 was 3.96 acre-feet per acre. 


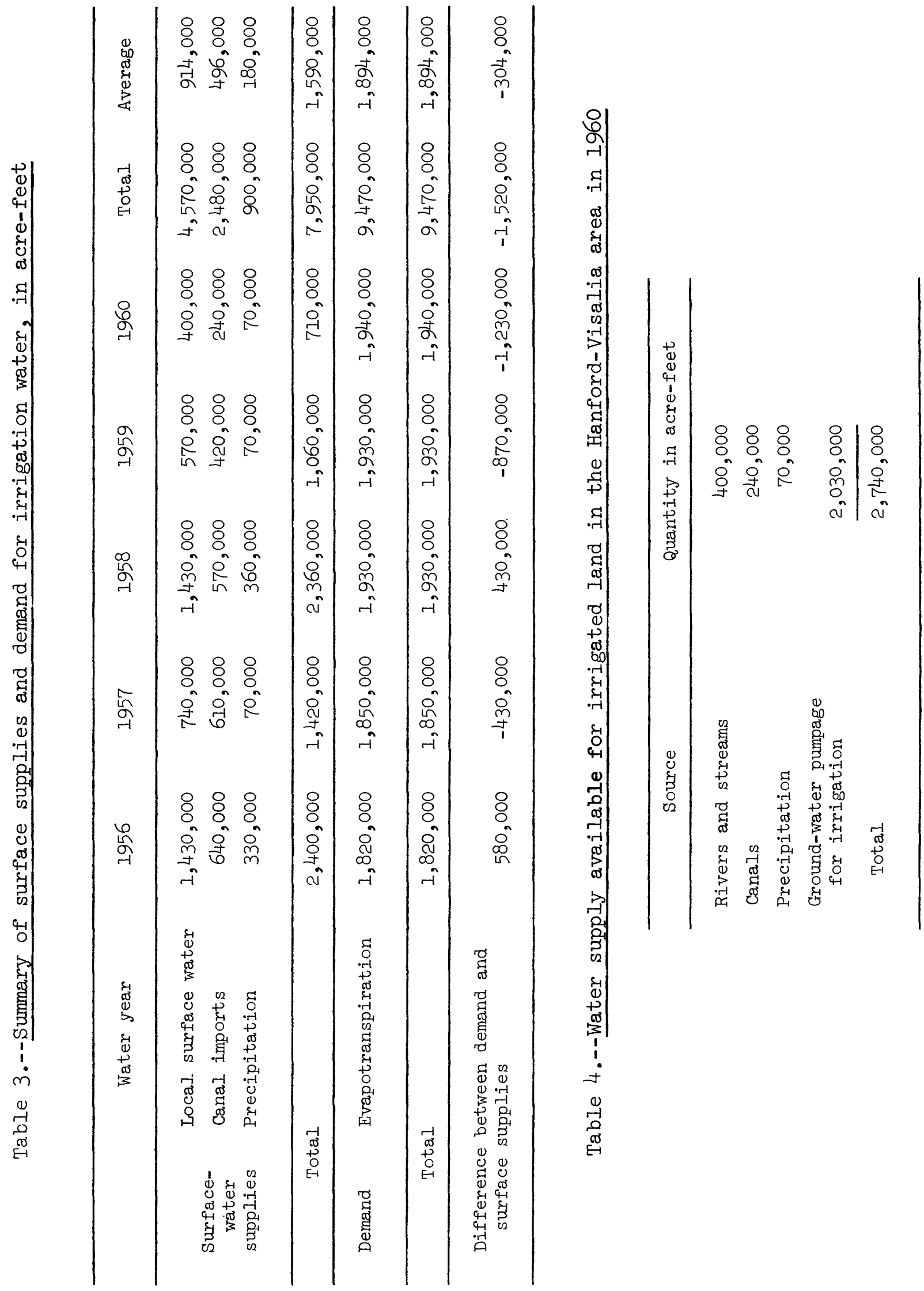




\section{CHEMICAL QUALITY OF WATER}

About 1,200 chemical analyses of ground water were available for the study of water quality in the Hanford-Visalia area. These analyses were obtained from various public and private sources and from the files of the Geological Survey. Some supplementary data were necessary and between May and July 1962, 34 samples of ground water for chemical analysis were collected at-sielected wells.

Chemical-quality data for surface water were obtained from published and unpublished records of the Geological Survey and the California Department of Water Resources. One sample of the runoff of Yokohl Creek (pl. 13) was collected for chemical analysis in February 1962 shortly after a period of heavy precipitation.

Most mineral constituents occur in ionic form in solution, although some occur as colloidal suspensions. Concentrations of mineral matter in water are conventionally expressed in $\mathrm{mg} / \mathrm{l}$ (milligrams per liter), but for significant chemical comparison of mineral constituents, it is convenient to express concentrations in chemical equivalents per million (epm). One equivalent per million represents one milligram equivalent weight of constituent in one liter of solution. Water is frequently classified according to its chemical character on the basis of percentage values of constituents in solution. A percentage value is the ratio, expressed in percent, of the concentration in equivalents per million of each cation or anion to the sum of cations or anions, respectively.

Water in which calcium amounts to 50 percent or more of the cations and bicarbonate amounts to 50 percent or more of the anions is designated a calcium bicarbonate water. If calcium and sodium were first and second in order of abundance among the cations but neither amounted to 50 percent of all the cations, the water would be designated calcium sodium bicarbonate. Similarly, if bicarbonate and sulfate were first and second in order of abundance among the anions but neither amounted to 50 percent of all the anions, the water would be designated calcium bicarbonate sulfate. Water is described as being of intermediate cation composition or intermediate anion composition when the principal cations or principal anions are present in approximately equal proportions.

The chemical composition of surface and ground water is shown diagramatically on plate 13. The pattern of each diagram is determined by the percentage of individual ions or groups of ions. 


\section{Surface Water}

The chemical quality of much of the ground water in the HanfordVisalia area is closely related to the quality of the surface water supplies that recharge the aquifers. Diagrams (pl. 13) representing the average composition of water from perennial streams are derived from samples collected during periods of high and low flow. The diagrams for intermittent streams were constructed from data obtained from single analyses. Because the intermittent streams differ from perennial streams in chemical quality of water and in duration of flow, they are discussed separately.

\section{Perennial Streams}

Water from Kaweah, Tule, and Kings Rivers is calcium bicarbonate in type with low dissolved-solids content. The general similarity of quality is shown by the chemical diagrams on plate 13. However, figure 9 indicates that there are minor differences in the chemicalccharacter of the water. Bar graphs shown in the figure were constructed from dischargeweighted averages of chemical analyses of runoff in each stream. The graphs show that water in Tule River has about three times the concentrat tion of dissolved solids found in water from the Kaweah and Kings Rivers. The Tule River drains an area of lower elevation than the Kaweah and Kings Rivers. Magnesium percentage is higher in water from the Kings River than in that from Kaweah or Tule Rivers. Regional geologic maps (Cohee, 1962) indicate that a proportionally larger area of the Kings River drainage basin is underlain by magnesium-rich metamorphic rocks.

Although seasonal deviations. from average chemical composition were not investigated, inspection of several analyses showed minor seasonal differences in total concentration of dissolved solids. In the spring and early summer when discharge is greatest, water in the Kaweah and Tule F Rivers shows low concentrations of dissolved solids and in late summer and early autumn when discharge is lowest, concentration is appreciably higher.

\section{Intermittent Streams}

Streams that drain the low foothills of the Sierra Nevada flow intermittently during winter and early spring. Because flow is erratic, only a few samples of runoff were collected for chemical analysis. Analyses of samples from three intermittent streams are shown in figure 9. The bar graphs indicate that intermittent streams have roughly 2 to 10 times the concentration of dissolved solids found in water from perennial streams. 


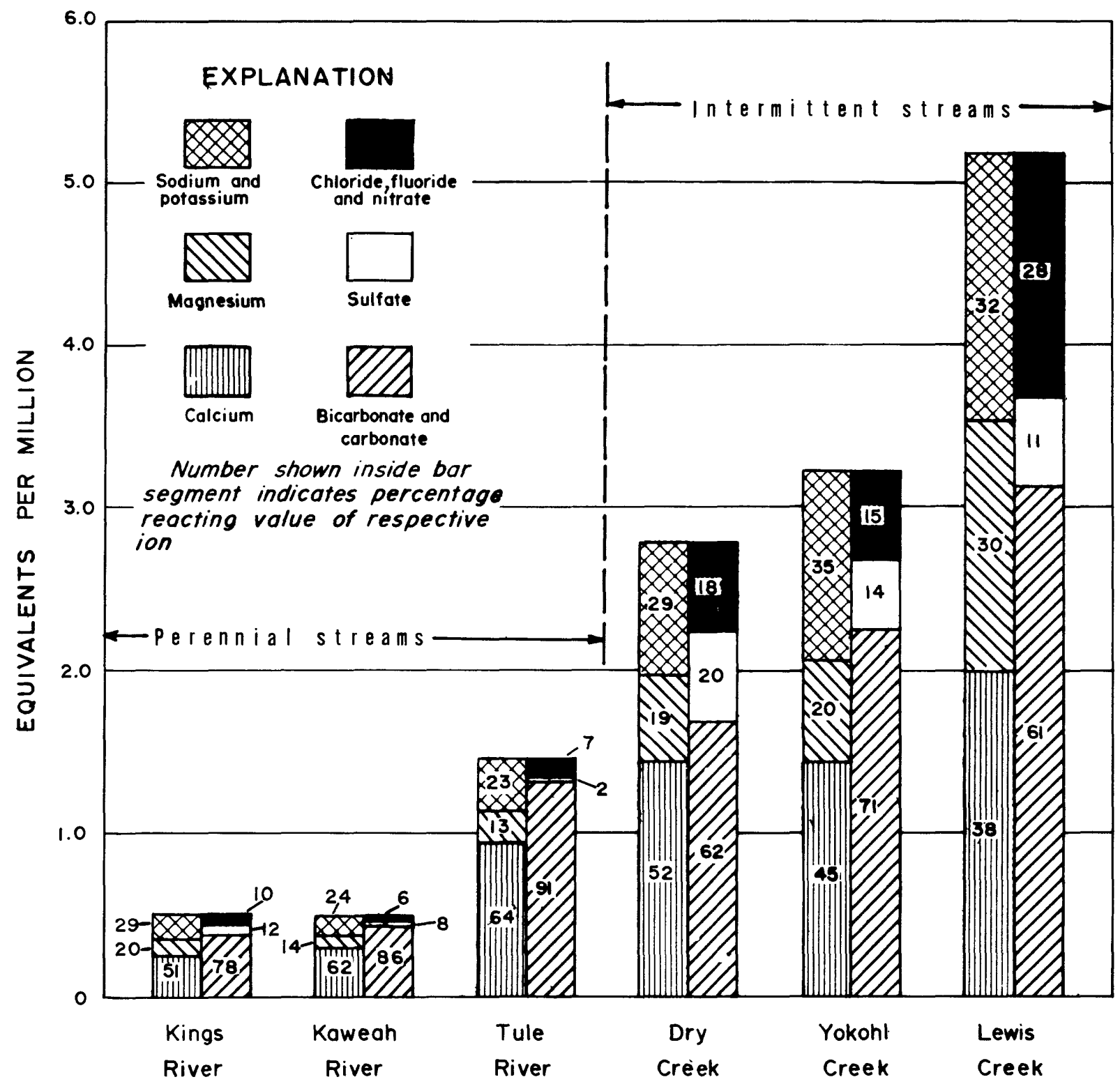

FIGURE 9. -Vertical bar graphs representing average chemical analyses of water from perennial sierra Nevada and intermittent foothill streams. 
Analyses from two of the streams, Dry Creek and YokohI Creek, have chemical characteristics similar to but more concentrated than the perennial streams. Water from Lewis Creek is more highly mineralized, and contains a higher percentage of magnesium than the others. A large part of the drainage basin of Lewis Creek is underlain by metamorphic and ultrabasic igneous rocks which presumably are the source of magnesium in the water. A comparison of ground-water samples, one from well 2lS/28E-22LI in granitic rocks, and two from wells 2lS/28E-25KI and 22S/28E-2IBI (pl. 13) in metamorphic rocks, indicates that water from wells in the metamorphic rocks is high in magnesium whereas that from granitic rocks is low.

\section{Ground Water}

Mendenhall and others (1916, p. 99) found that ground water within the geographical subdivisions of the San Joaquin Valley north of Kern County was of sufficiently uniform quality that ground water could be classified according to east-side, west-side, and axial-trough types. In general, ground water on the east side of the valley was of the bicarbonate type with low dissolved-solids content; ground water on the west side of the valley was highly mineralized and mainly of the sulfate type, and ground water in the axial trough was alkaline and variable in concentration and chemical character.

Later, Davis and others (1959, p. 175-177) followed the system of Mendenhall, grouping ground water on the basis of geographical location, but did not limit its application to any one section of the valley. They further observed that there was a general relation between ground-water quality and depth. Ground water was subdivided into three vertical zones: (1) Water that was unconfined or semiconfined and had fairly free communication with the land surface, (2) water that was confined below the diatomaceous clay (E-clay of this report) and other confining beds, and (3) brackish and saline connate water or modified connate water that underlies most of the valley down to the basement complex. Top of brackish water as shown on cross sections (pls. 4, 5, and 7) is based on electriclog interpretation at depth, where a sharp departure on the short normal resistivity curve is accompanied by a reversal of the long normal curve (LeRoy, 1951, p. 365). 
The areal and vertical grouping of ground water devised by Mendenhall and others (1916) and by Davis and others (1959) was adapted for this report. Boundaries of certain water types coincide closely with geologic boundaries and variations in quality and character of ground water within certain geologic units probably are related to recharge sources. This interpretation is demonstrated in maps and in cross sections, by analyses of water obtained from U.S. Bureau of Reclamation core holes, and from irrigation and domestic wells. Plate 14 indicates the areal extent and summarizes in part the chemical character of east-side and axial-trough ground-water types. East-side ground water occurs in deposits of Sierra Nevada origin and axial-trough ground water occurs in the Sierra Nevada deposits in the valley trough. West-side ground water occurs in deposits of Coast Range origin, has limited extent in the Hanford-Visalia area and is not shown on plate 14 .

East-Side Ground Water

Ground water in the alluvial deposits of the Kaweah, Tule, and lower part of the Kings River fans is low in dissolved constituents. Calcium and bicarbonate, the predominant cation and anion in water of the Kaweah, Tule, and Kings Rivers, also predominate in water from the younger alluvium and the oxidized older alluvium which underlie these streams (p1. 14). Sodium is the predominant cation in ground water in the continental deposits and in the reduced older alluvium. However, in interfan areas ( $\mathrm{Is.}$ I and 14), where recharge is from intermittent streams, calcium, magnesium, and sodium approach equal concentrations and chloride may occur in concentrations greater than $I$ equivalent per million.

In the younger alluvium and oxidized older alluvium.--Where recharge is from the Kaweah, Tule, and Kings Rivers, ground water in the younger alluvium and oxidized older alluvium is generally the calcium bicarbonate type. Dissolved solids range from 100 to $270 \mathrm{mg} / 1$ and the concentration of sodium is generally less than 40 percent. Ground water in the younger alluvium above the A-clay north of a line connecting Lemoore, Guernsey, and Corcoran (pl. 13) is calcium bicarbonate type. Beneath the A-clay in this area ground water is of the sodium bicarbonate type. In interfan areas near Lewis and Cottonwood Creeks (pl. 14), chloride generally occurs in concentrations greater than $l$ epm and in some water it is the predominant anion rather than bicarbonate. Calcium, magnesium, and sodium are present in about equal proportions. The concentration of dissolved solids in the interfan areas ranges from 270 to $650 \mathrm{mg} / \mathrm{l}$. 
Although chemical character of the ground water closely resembles the chemical character of water in the perennial and intermittent streams, there is a difference in the concentration of dissolved solids. This difference is shown by chemical diagrams on plate 13. Well 17S/22E-2HI, less than 150 feet in depth, yields calcium bicarbonate type water similar in character to that of water in the Kings River. However, the dissolvedsolids concentration of the ground water is almost three times that of the surface water ( 109 and $36 \mathrm{mg} / 1$, respectively). The chemical diagrams for wells 17S/27E-34RI and 2lS/27E-20GI, are very similar to those for surface water in the Kaweah and Tule Rivers but show a higher dissolved-solids content.

Ground water in interfan areas--the areas between the Kaweah, Tule, and Kings Rivers--is very similar in chemical character to water in intermittent streams. For example, the chemical diagram of water from well 18S/27E-31Bl (pl. 13), less than 90 feet in depth, is similar to the diagram for water of nearby Yokohl Creek.

In the continental deposits and reduced older alluvium.--Beneath the Kaweah, Tule, and lower part of the Kings River fans, chemical analyses indicate that ground water in the oxidized and reduced continental deposits and in the reduced older alluvium generally is of the sodium bicarbonate type (pls. 4, 7, 13, and fig. 9). The percent sodium in ground water is generally greater than 70 , and the concentration of dissolved solids ranges from 100 to $500 \mathrm{mg} / \mathrm{l}$. In many analyses concentration of dissolved solids is less than that of water in the overlying oxidized older alluvium (pl. 7, section $\left.E-E^{\prime}\right)$.

In parts of the Lewis Creek interfan area adjacent to the foothills at Lindsay, ground water is of intermediate cation composition and contains more than 1 epm of chloride. Dissolved solids range from 100 to $500 \mathrm{mg} / \mathrm{l}$. In many analyses the percentage of magnesium was greater than that of calcium (well 19S/26E-23Q1, pl. 7, section D-D'). Analysis of this water and water from other wells in the vicinity are shown as chemical diagrams on plate 13 and resemble the diagram representing surface water from Lewis Creek.

Axial-Trough Ground Water

In the valley trough, ground water in the reduced continental deposits and in the older and younger alluvium is generally high in mineral. constituents. Chemical character and dissolved-solids concentration are variable because the axial trough is the lowest part of the valley. The ground water is a mixture of different types that occur on the valley flanks, modified during migration through the deposits. For convenience, axial-trough ground water is discussed as (1) above the A-clay, (2) between the E-clay and the A-clay, and (3) below the E-clay. 


\title{
ARTIFICIAL RECHARGE
}

\author{
Existing Sites
}

\begin{abstract}
Within the study area, river channels and recharge basins or pits, reservoirs, unlined canals and other facilities have been developed or used by irrigation districts for artificial recharge of the ground-water reservoir. The Kaweah Delta Water Conservation District operates river channels, canals, and recharge basins; the Kings County Water District has developed river channels; the Lindsay-Strathmore Irrigation District has experimented with wells (F. D. Trauger, in Todd, 1959, p. 95); and the Lower Tule River Irrigation District utilizes recharge basins and river channels. The locations of recharge basins and reservoirs, all underlain by older and younger alluvium, are shown on plate 2 . Most of the recharge basins are converted gravel pits or consist of levees constructed from earth which was graded from the floor of the basin.
\end{abstract}

\section{Recharge Basins}

The recharge percolation rates and capacities of recharge basins in the Hanford-Visalia area are given in table 5. The percolation rates reported by the Kaweah Delta Water Conservation District for two basins are the results obtained from several months' use but whether the remaining basins would maintain the reported percolation rates over extended periods is not known. For example, the percolation rate of 0.94 foot per day, was measured in recharge basin 10, after the basin was operated from February 22 to April 16, 1956. The basin received an average of 55 second-foot of water during the period and did not overflow. Water was again diverted into the basin from May 1 to June 20 at an average rate of 75 second-foot or 150 acre-feet per day and this flow was maintained when the basin was full. Data and procedures used for obtaining the percolation rate in recharge basin 3 were given by C. Eaton (in Todd, 1959, p. 26). The recharge capacity of basins in the Corcoran and Lower Tule River Irrigation Districts are estimates by officials and ditch tenders of the districts, who took into consideration the fact that in some cases the floors of the basins were not completely flooded at the time that the recharge capacity was estimated.

Total artificial recharge capacity of 24 recharge basins and other miscellaneous installations within the Kaweah Delta Water Conservation District, of three reservoirs within the Corcoran Irrigation District, and of seven recharge basins in the Lower Tule River Irrigation District, is estimated at 1,340 acre-feet per day. The average rate of percolation for the basins is about 0.7 foot per day. In general, the smaller recharge basins have higher percolation rates, which presumably is due to lateral spreading of water. 
concentration of bicarbonate ion, the presence of hydrogen sulfide and carbon dioxide gases, and the absence of sulfate, indicate that the water below the E-clay has undergone sulfate reduction (Hem, 1959, p. 223-224).

\section{Chemical Quality of Ground Water in Relation to Use}

Agriculture, supported by irrigation, is by far the most important industry in the Hanford-Visalia area and is the biggest user of water. Consequently, the quality of water for irrigation is of primary importance but water suitable for production of agricultural products and domestic consumption also is required.

\section{Irrigation}

The suitability of water for irrigation and other agricultural uses depends primarily upon the salinity or total mineral content, and the sodium content relative to that of other cations. Other mineral constituents such as boron were not studied in detail because they are of secondary importance or have been studied by other agencies (California Department of Water Resources, 1961).

Salinity.--The staff of the U.S. Salinity Laboratory (1954) developed a method based on specific conductance for classifying water used for irrigation. Water having a specific conductance less than 250 micromhos is classed $\mathrm{Cl}$, water with a specific conductance of 250-750 micromhos is classed $\mathrm{C} 2$, water with a specific conductance of 750-2,250 micromhos is classed C3, and water with a specific conductance greater than 2,250 micromhos is classed $\mathrm{C}_{4}$.

Low-salinity water ( $\mathrm{Cl}$ ) can be used for irrigation of most crops and on most soils with little likelihood that soil salinity will develop. Some leaching is required, but this occurs under normal irrigation practices except in soils of extremely low permeability. Medium-salinity water ( $\mathrm{C} 2$ ) can be used if a moderate amount of leaching occurs. Plants with moderate salt tolerance can be grown in most cases without special practices for salinity control. High-salinity water (C3) cannot be used on soils with restricted drainage. Even with adequate drainage, special management for salinity control may be required and plants with good salt tolerance should be selected. Very high salinity water (c4) may be used under favorable circumstances. The soils must be permeable, drainage must be adequate, and irrigation water must be applied in excess to provide sufficient leaching. 
The salinity classification system developed by the U.S. Salinity Laboratory was used for classifying ground water in the most heavily pumped and most permeable geologic units (pl. 13); the older alluvium, and the reduced continental deposits. Low-salinity ( $\mathrm{Cl}$ ) water occurs beneath the channels of the Kaweah, Tule, and Kings Rivers, and beneath the main irrigation canals, where recharge occurs from surface-water supplies. High-salinity water (C3) that occurs between Lindsay and Exeter is believed to be from the saline water zone in the reduced continental deposits (section D-D', pl. 7). Also, wells in that area probably tap the underlying marine rocks. Elsewhere high-salinity water (C3) was mapped along the channel of Cross Creek and in the confined aquifers below Tulare Lake Bed. Throughout the remainder of the area medium-salinity water (C2) occurs. Water classed as very high salinity ( 4 ) is not extensive enough to be shown. Water of that category occurs in flood basin and underlying lacustrine and marsh deposits beneath Tulare Lake Bed, and at depth in the marine rocks.

Sodium.--Sodium possesses the property of displacing calcium and magnesium on soil particles if its concentration is greater than that of the other cations in solution. This exchange causes soils to disperse and become impermeable (Wilcox, 1948, p. 10-12). Percent sodium is a common index of the alkali hazard of any given water. If the percent sodium of water is much in excess of 50, use of the water for irrigation may result in soil dispersion. Ground water in the continental deposits and in the reduced older alluvium contain sodium in excess of 50 percent.

Domestic Use

Drinking water standards established by the U.S. Public Health Service (1962) for use on interstate carriers specify the following concentrations of chemical constituents as the maximum permitted for potable water, if other more suitable supplies are not available:

$\begin{array}{lc}\text { Iron } & 0.3 \mathrm{mg} / \mathrm{I} \\ \text { Nitrate } & 45 \\ \text { Chloride } & 250 \\ \text { Sulfate } & 250 \\ \text { Dissolved solids } & 500\end{array}$

Recommended limits for the concentration of fluoride in water vary according to average annual air temperature. At $90^{\circ} \mathrm{F}$ the maximum concentration of fluoride would be about $1.4 \mathrm{mg} / \mathrm{I}$; at $50^{\circ} \mathrm{F}$ the maximum would be about $2.4 \mathrm{mg} / 1$. These standards have been accepted by the American Water Works Association as the minimum standards for all public water supplies. Accordingly, they serve as criter in evaluating water for general domestic use. 
Ground water containing dissolved solids in excess of $500 \mathrm{mg} / \mathrm{l}$ occurs for the most part in the high-salinity areas (c3) outlined on plate 13. Frequently the C3 water has chloride or sulfate concentration exceeding the limits referred to above. In some areas, water more suitable for domestic use may be obtained by wells perforated at depths different from those of the present wells. Wells of the Stratford Public Utility District, for example, yield water which contains more than $900 \mathrm{mg} / \mathrm{I}$ of dissolved solids and almost $300 \mathrm{mg} / \mathrm{l}$ of sulfate. These wells are perforated from about 450 to 735 feet below land surface. Several irrigation wells in the vicinity of Stratford that are perforated beneath the E-clay (more than 600 feet below land surface) yield water containing about $500 \mathrm{mg} / \mathrm{l}$ dissolved solids and almost no sulfate.

Ground water containing nitrate in concentration greater than $45 \mathrm{mg} / 1$ occurs sporadically near the foothills of the Sierra Nevada. Generally, where the concentration of nitrate exceeds $45 \mathrm{mg} / 1$, the concentration of dissolved solids exceeds $400 \mathrm{mg} / \mathrm{l}$.

Within the report area, available chemical analyses do not indicate that fluoride occurrèd in concentrations greater than $1.5 \mathrm{mg} / \mathrm{l}$.

Water for domestic use is usually rated on the basis of hardness or ability to form scum or curd with soap. The following table gives adjective ratings based on ranges of concentration of hardness expressed in milligrams per liter of calcium carbonate:

Hardness Range (mg/1)

$$
0-60
$$

61-120

121-180

Greater than 180

\section{Adjective Rating}

Soft

Moderately hard

Hard

Very hard

Generally, water having a hardness less than $120 \mathrm{mg} / \mathrm{l}$ need not be softened, that between 120 and $180 \mathrm{mg} / 1$ may require softening, and that exceeding $180 \mathrm{mg} / 1$ requires softening for most uses. Most of the water classified as hard or very hard occurs in interfan areas between the Kings, Kaweah, and Tule Rivers; most of the water classified soft or moderately hard occurs on the alluvial fans and in the axial trough. 
Above the A-clay.--Ground water in the younger alluvium, south of a line connecting Corcoran, Guernsey, and Lemoore, is generally of the sodium bicarbonate type (pl. 14). Dissolved solids range from 200 to $500 \mathrm{mg} / \mathrm{l}$. East of Lemoore along the channel of the Kings River, wells penetrating younger alluvium, alluvium, undifferentiated, and flood-basin deposits, obtain sulfate water of intermediate cation composition ( $\mathrm{pl}$. 5) with dissolved solids ranging from 200 to $3,000 \mathrm{mg} / \mathrm{l}$.

In the flood-basin deposits underlying Tulare Lake Bed, the quality of ground water is variable. For example, water from well 20S/2OE-23MI, 11 feet deep, is of sufficiently good quality (dissolved-solids content, $878 \mathrm{mg} / \mathrm{l}$ ) that it can be used for domestic purposes. Water from well 2OS/2OE-12MI, about 2 miles northeast of 2OS/2OE-23MI, has a dissolved-solids content of $3,030 \mathrm{mg} / 1$.

Between the A-and E-clays.--In the axial trough of the valley, ground water confined between the A-and E-clays is mainly of two chemical types (pl. 14). Ground water is of the sodium bicarbonate type in a belt from Lemoore to Corcoran, but sodium bicarbonate to sodium sulfate type is found near stratford.

Ground water from Corcoran to Lemoore between the A-and E-clays is of the sodium bicarbonate type. Dissolved solids range from about 200 to $1,000 \mathrm{mg} / \mathrm{I}$ and the percent sodium is generally greater than 70 . Chloride increases south of Lemoore as shown by the chemical diagrams in figure 9 and by well 22S/22E-12A2 (pl. 4).

Confined ground water near Stratford is of the sodium bicarbonate to sodium sulfate type (pl. 13). Sulfate occurs unpredictably but generally increases in concentration to the southwest. Dissolved solids range from about 250 to $1,100 \mathrm{mg} / \mathrm{I}$, and sodium generally constitutes more than 70 percent of the cations.

Below the E-clay.--In the axial trough, ground water below the E-clay is either sodium bicarbonate or sodium chloride type (pl. 15). Dissolved constituents range from more than $1,000 \mathrm{mg} / 1$ in the southwest corner of the area to $500 \mathrm{mg} / \mathrm{I}$ north and east near stratford and Corcoran. Bicarbonate ranges from 2 to $12 \mathrm{epm}$ and sodium makes up more than 70 percent of the cations. The aralyses indicated that chloride increased from northeast to southwest.

Near stratford, sulfate is a major anionic constituent of the ground water above the E-clay but below the E-clay, sulfate is almost completely absent. This change in chemical character is shown in well 20S/19E-25J1, perforated exclusively above the E-clay, which yields a sodium sulfate bicarbonate water in which the concentration of sulfate amounts to 5 epm. Wells perforated both above and below the E-clay yield water in which sulfate is one of the major anions. For example, well 20S/18E-14JI contains 11 epm of sulfate--68 percent of the anions. In contrast, wells 20S/19E-36Cl, 21S/2OE-18DI, and 21S/2OE-3ODI--all perforated below the E-clay--yield water in which sulfate ion is nearly absent. The high 


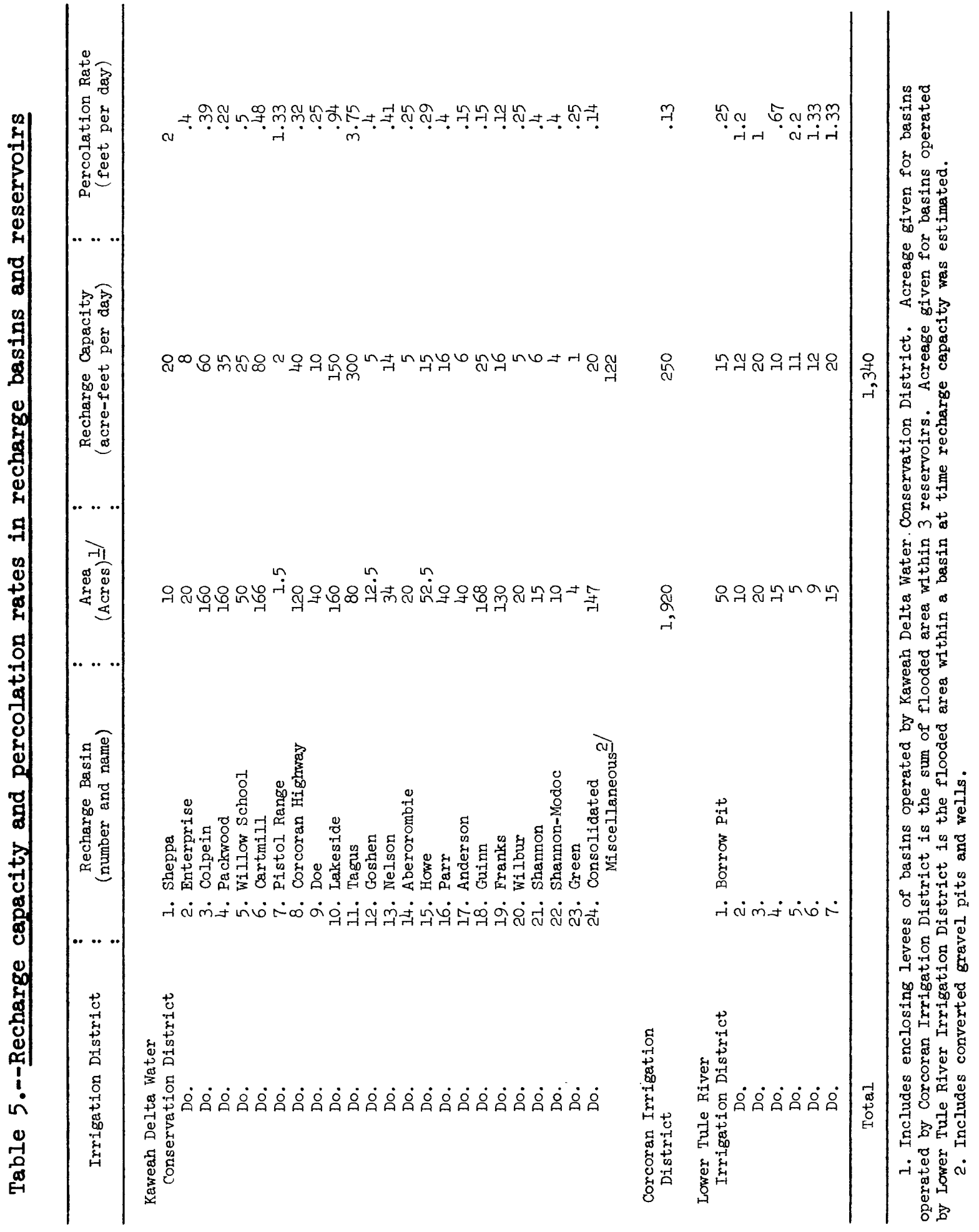




\section{River Channels}

According to officials of the Kings County Water District, an 8-mile stretch of the Kings River immediately southwest of U.S. Highway 99 has been altered with four check dams for artificial recharge. In 1958, 18,000 acre-feet of water was diverted into the channel and the entire amount was infiltrated in the first $2 \frac{1}{2}$ miles of channel.

The Kaweah and Tule River channels have been utilized for recharge purposes, but data are not available, and therefore the total recharge capacity of these facilities could not be estimated.

\section{Potential Sites}

Much of the ground-water reservoir underlain by the older and younger alluvium can be developed for artificial recharge and cyclic storage of water. Among the pertinent features that must be considered for effective artificial recharge are, permeability of deposits at the surface, and permeability of underlying beds. Another characteristic, quality of the contained water, is not explored here. Areas most suitable for recharge occur on the Kaweah, Tule, and Kings River fans, east of U.S. Highway 99, and are underlain by younger and older alluvium. Artificial recharge would be impractical in areas underlain by flood-basin deposits and in areas underlain by the continental deposits.

The surface permeability of alluvium is to a large degree dependent upon the texture and the stage of soil development. Soil-forming processes in arid regions may form hardpan or claypan which makes the soil nearly impermeable. The younger alluvium ( $\mathrm{pl} .2$ ) has little or no soil development and, where composed mainly of sand, it is highly permeable and will readily transmit water from recharge basins to the water table. However, the underlying older alluvium contains well-developed soil profiles and thick, impermeable, hardpan horizons which may occur above the water table. Test drilling is recommended at sites proposed for recharge basins to locate hardpan horizons if present, and to determine the permeability of the underlying beds. Where hardpan occurs at shallow depth beneath the surface, recharge basins may be constructed as pits, whose bottom is below any impermeable horizon.

Impermeable lacustrine clay underlies large areas of the valley and interfingers with the older alluvium and the continental deposits. In many areas deposits above the lacustrine clay are highly permeable but the clay limits the depth to which the aquifer can be recharged effectively by surface operations. The E-clay occurs at a depth of 200 to 450 feet below land surface (p1.8) in most of the area west of U.S. Highway 99. Four impermeable lacustrine clay beds occur above the E-clay near Hanford and Lemoore. 


\section{SELECTED REFERENCES}

Albright, M. B., Hluza, A. G., and Sullivan, J. C., 1957, Mount Poso oil field, in Summary of operations, California oil fields: California Div. OiI and Gas, v. 43, no. 2, p. 5-20.

Anderson, F. M., 1905, A stratigraphic study in the Mount Diablo Range of California: California Acad. Sci. Proc., 3d ser., v. 2, p.155-248.

Arnold, Ralph, and Anderson, Robert, 1910, Geology and oil resources of the Coalinga district, California: U.S. Geol. Survey Bull. 398, 354 p.

Barbat, W. F., and Galloway, John, 1934, San Joaquin Clay, California: Am. Assoc. Petroleum Geologists Bull., v. I8, no. 4, p. 476-499.

Blaney, H. F., 1928, Disposal of rainfall, pt. 2, chap. 4, in Santa Ana investigation: California Div. Eng. and Irrig., Bul1. 19, p. 152-163.

Bull, W. B., 1964, Alluvial fans and near-surface subsidence in western Fresno County, California: U.S. Geol. Survey Prof. Paper 437-A, p. A1-A71.

1965, Land subsidence in the Los Banos-Kettleman City area, California, 1959-63: U.S. Geol. Survey open-file map, scale 1:250,000.

California Department of Water Resources, 1957, The California water plan: Bul1. 3, $246 \mathrm{p}$.

1961, Study of boron in citrus packing plant waste, discharges, Fresno and Tulare Counties: California Dept. Water Resources rept., 33 p.

California Division of Water Resources, 1953, Effects of the disposal of orange packing plant wastes, Lindsay-Lemoncove area, Tulare County: California Div. Water Resources rept., 33 p.

California State Water Resources Board, 1955, Water utilization and requirements of California: Bull. 2, $227 \mathrm{p}$. and app.

Cohee, G. V., 1962, Tectonic map of the United States: U.S. Geol. Survey and Am. Assoc. Petroleum Geologists map.

Curtis, G. H., Evernden, J. F., and Lipson, J., 1958, Age determination of some granitic rocks in California by the potassium-argon method: California Dept. Nat. Resources, Div. Mines Spec. Rept. 54, 16 p.

Dale, R. H., French, J.J., and Gordon, G. V., 1966, Ground-water geology and hydrology of the Kern River alluvial fan area, California:

U.S. Geol. Survey open-file rept., $92 \mathrm{p}$. 
Davis, G. H., and Green, J. H., 1962, Structural control of interior drainage, southern San Joaquin Valley, California: Art. 146 in U.S. Geol. Survey Prof. Paper: 450-D, p. D89-D91.

Davis, G. H. ..Green, J. H., Olmsted, F. H., and Brown, D..W., 1959, Groundwater conditions and storage capacity in the San Joaquin Valley, California: U.S. Geol. Survey, Watér-Supply Paper 1469, 287 p.

Davis, G. H., Lofgren, B. E., and Mack, Seymour, 1964, Use of ground-water reservoirs for storage of surface water in the San joa quin Valley, California: U.S. Geol. Survey Water-Supply Paper 1618, 125 p.

Davis, G. H., and Poland; J. F., 1957, Ground-water conditions in the Mendota-Huron area, Fresno and Kings Counties, California: U.S. Geol. Survey Water-Supply Paper 1360-G, p. 409-588.

Davis,S. N., and Hal I, F, R., 1959, Water Quality of eastern stanislaus and northerm Merced Counties, California: Stanford Univ. Pub., Geol. sci., v. 6, no. 1, 56 p.

Diepenbrock, Alex, 1933, Mount Poso oil field; in Summary of operations, California oil fields: California Div. Oil and Gas, v. 19, no.2, p. 5-35.

Durrell, Cordell, 1940, Metamorphism in the southern Sierra Nevada northeast of Visalia, California: California Univ., Dept. Geol. Sci., Bull. v. 25, no. 1,118 " $\mathrm{p}$.

Eaton, F. M., 1950, Significance of carbonates in irrigation waters: Soil sci., y. 69, p. 123-133.

Prink, J.W., and Kues, H. A., 1954, Corcoran Clay, a "Pleistocene lacustrine deposit in San Joaquin Valley, California: Am. Assoc. Petroleum Geologists Bull., v. 38, no. 11, p. 2357-2371.

Gordon, G. V., and Croft, M. G., 1964, Data for wells and streams in the Hanford-Visalia area, San Joaquin Valley, California: U.S. Geol. Survey open-file rept:, $432 \mathrm{p}$.

Grunsky, C. E., 1898, Irrigation near Bakersfield, California: U.S. Geol. Survey Water-Supply Paper 17, 96 p.-

1898, Irrigation neâr Fresno, California: U.S. Geol. Survey. WaterSupply Paper 18, $94^{*} \mathrm{p}$.

Hall; Charles, 1965, Pleistocene deformation in the vicinity of Mile 8 Pumping Plant: Internat. Assoc. for Quaternary Research Guidebook for Field Conference I, Northern Great Basin and Californiá, p.I42-145.

Hardinǵ, S. T, 1927, Ground-water resources of southern San Joaquin Valley: California Div. Eng. and Irrig. and Wäter Rights Buil. $11,146 \mathrm{p}$. 
Harr, M. E., 1962, Ground water and seepage: New York, McGraw-Hill Book Co., Inc., $315 \mathrm{p}$.

Hem, J. D., 1959, Study and interpretation of the chemical characteristics of natural water: U.S. Geol. Survey Water-Supply Paper 1473, 269 p.

Hilton, G. S., McClelland, E. J., Klausing, R. L., and Kunkel, Fred, 1963, Geology, hydrology, and quality of water in the Terra Bella-Lost Hills area, San Joaquin Valley, California: U.S. Geol. Survey open-file rept., $158 \mathrm{p}$.

Hunter, G. W., 1952, Riverdale oil field, in Summary of operations, California oil fields: California Div. Oil and Gas, v. 38, no. 2, p. 19-24.

Inter-Agency Committee on Land Subsidence in the San Joaquin Valley, 1958, Progress report on land-subsidence inverstigations in the San Joaquin Valley, California, through 1957: Sacramento, Calif. open-file rept., $160 \mathrm{p}$.

Ireland, R. L., 1963, Description of wells in the Los Banos-Kettleman City area; Merced, Fresno, and Kings Counties, California: U.S. Geol. Survey open-file rept., mimeo., $519 \mathrm{p}$.

Johnson, A. I., Moston, R. P., and Morris, D. A., 1965, Physical and hydrologic properties of water-bearing deposits in subsiding areas in central California: U.S. Geol. Survey open-file rept., $166 \mathrm{p}$. [in press as Prof. Paper 497-A].

Klausing, R. L., and Lohman, K. E. 1964, Upper Pliocene marine strata on the east side of the San Joaquin Valley, California: Art. 124 in U.S. Geol. Survey Prof. Paper 475-D, p. D14-DI7.

Le Roy, L. W., 1951, Subsurface geologic methods (a symposium): Colorado School Mines, Golden, Colo., 1156 p.

Lofgren, B. E., and Klausing, R. L., 1960, Land subsidence in the TulareWasco area, Califarnia, 1957-59: U.S. Geol. Survey open-file map,. scale 1:125,000.

May, J. C., and Hewitt, R. L., 1948, The basement complex in well samples from the Sacramento and San Joaquin Valleys, California: California Jour. Mines and Geology, v. 44, no. 2, p. 129-158.

Meade, R. H., 1967, Petrology of sediments underlying areas of land subsidence in central California: U.S. Geol. Survey Prof. Paper 497-C, p. Cl-C83.

Mendenhall, W. C., Dole, R. B., and Stabler, Herman, 1916, Ground water in San Joaquin Valley, California: U.S. Geol. Survey Water-Supply Paper 398,310 p. 
Olmsted, F. H., and Davis, G. H., 196I, Geologic features and ground-water storage capacity of the Sacramento Valley, California: U.S. Geol. Survey Water-Supply Paper 1497, $241 \mathrm{p}$.

Park, W. H., and Weddle, J. R., 1959, Correlation study of southern San Joaquin Valley, in Summary of operations, California oil fields: California Div. Oil and Gas, v. 45, no. 1, p. 33-34.

Piper, A. M., Gale, H. S., Thomas, H. E., and Robinson, T. W., 1939, Geology and ground-water hydrology of the Mokelumne area, California: U.S. Geol. Survey Water-Supply Paper 780, 230 p.

Poland, J. F., 1959, Hydrology of the Long Beach-Santa Ana area, California: U.S. Geol. Survey Water-Supply Paper 1471, 257 p.

1960, Land subsidence in the San Joaquin Valley, California, and its effect on estimates of ground-water resources: Internat. Assoc. Sci. Hydrology, Comm. Subterranean Waters, Pub. no. 52, p. 324-335.

Poland, J. F., and Davis, G. H., 1956, Subsidence of the land surface in the Tulare-Wasco (Delano) and Los Banos-Kettleman City areas, San Joaquin Valley;, California: Am. Geophys. Union Trans., v. 37, no. $3,10 \mathrm{p}$.

Poland, J. F., and Evenson, R. E., 1966, Hydrology and land subsidence, Great Central Valley, California, in Geology of northern California: California Div. Mines and Geology, Bull. 190, p. 239-247.

Schoellhamer, J. E., and Kinney, D. M., 1953, Geology of a part of Tumey and Panoche Hills, Fresno County, California: U.S. Geol. Survey Oil and Gas Inv., Map OM-128.

Smith, M. B., 1964, Map showing distribution and configuration of basement rocks in California (Sheet 1 , north half) (Sheet 2 , south half): U.S. Geol. Survey Oil and Gas Inv., Map OM-2l5.

Storie, R. E., Owen, B. C., Carpenter, E. S., Layton, M. H., and Leighty, W. J., 1940, Soil survey of the Visalia area, California: U.S. Dept. Agriculture, Ser. 1935, no. 16, 96 p.

Taylor, D. W., 1966, Summary of North American Blancan nonmarine Mollusks: Malacologia, v. 4, no. I, p. I-172.

Thomasson, H. G., Jr., Olmsted, F. H., and LeRoux, E. F., 1960, Geology, water resources and usable ground-water storage capacity of part of Solano County, California: U.S. Geol. Survey Water-Supply Paper 1464 , $693 \mathrm{p}$.

Tickell, F. G., 1921, A method for the graphical interpretation of water analysis, in Summary of operations, California oil fields: California Div. Oil and Gas, v. 6, no. 9, p. 7-12. 
Todd, D. K., 1959, Annotated bibliography on artificial recharge of ground water through 1954: U.S. Geol. Survey Water-Supply Paper 1477, 115 p.

U.S. Department of Agriculture, 1955, The yearbook of agriculture--water: Washington, D.C., U.S. Govt. Printing Office, 751 p.

U.S. Public Health Service, 1962, Drinking water standards, 1962:

Pub. 956, $61 \mathrm{p}$.

U.S. Salinity Laboratory Staff, 1954, Diagnosis and improvement of saline and alkali soils: U.S. Dept. Agr. Handb. 60,160 p.

Wilcox, L. V., 1948, The quality of water for irrigation use: U.S. Dept. Agriculture Tech. Bull. no. $962,40 \mathrm{p}$.

Wilcox, L...V., Blair, G. Y., and Bower, C. A., 1954, Effect of bicarbonate on suitability of water for irrigation: Soil sci., v. 77, p.259-266:

Wilhelm, V. H., and Saunders, L. W., 1927, Report on the Mount Poso oil field, in Summary of operations, California oil fields: California Div. Mines and Mining, v. 12, no. 7, p. 5-12.

Wilson, H. D., Jr., 1959, Ground-water appraisal of Santa Ynez River basin, Santa Barbara County, California, 1945-52: U.S. Geol. Survey WaterSupply Paper 1467, 119.p.

Wood, P. R., and Dale, R. H., 1964, Geology and ground-water features of the Edison-Maricopa area, Kern County, California: U.S. Geol. Survey Water-Supply Paper 1656, $108 \mathrm{p}$.

Wood, P. R., and Davis, G. H., 1959, Ground-water conditions in the Avenal-McKittrick area Kings and Kern Counties, California: U.S. Geol. Survey Water-Supply Paper 1457, $141 \mathrm{p}$.

Woodring, W. P., Stewart, Ralph, and Richards, R. W., 1940, Geology of the Kettleman Hills oil field; California: U.S. Geol. Survey Prof.

Paper $195,170 \mathrm{p}$. 